\title{
Polish coastal dunes - affecting factors and morphology
}

\author{
Tomasz A. Łabuz \\ Institute of Marine Sciences, University of Szczecin, Poland, labuztom@univ.szczecin.pl
}

\begin{abstract}
This article describe Polish coastal dunes and the factors influencing their development. The Polish coast is $500 \mathrm{~km}$ long and mainly exposed for a northerly direction. It is a part of the southern Baltic shore. The Polish coast is composed of mostly loose sand, till and peat. Because the coast hardiness is so weak, it is under constant threat from storm surges as well as human impact caused by rapid infrastructure development and the coastal protection measures put in place to try and protect it. These protection measures destabilize the natural coast dynamics and rebuilding process. Almost $85 \%$ of the shoreline is built up by sandy aeolian deposits and covered by different dune types. Among them are typical foredunes or inland dunes in eroded coastal areas. The second type of dune coasts are built up by land dunes, which appear on the coast as a result of sea erosion causing land regression. Sometimes dunes can be found over moraine deposits or in front of moraine old cliffs. Nowadays these habitats are heavily threatened by storm surges and human activity. In some places there is an accumulation that leads to new ridge developments. This article describes these issues with an emphasis on the present dynamics of Poland's coastal areas.
\end{abstract}

Key words: dune coast, dune types, dune dynamics, factors impact, Polish Baltic coast

\section{Introduction}

The coastal dunes show a great deal of variety in form, related to their sedimentation, their climatic settings past and present, and ecological factors influencing their associated variations (Bird 1969, 1990, Carter 1988, Carter, Wilson 1990). They are well known amongst the world's coastlines (e.g. Bird 1969, Hesp 1981, 1984, 1987, Carter, Wilson 1990, Psuty 1988, 1990, Arens 1994, Nordstrom 2000 and others), and are well developed on sandy barriers where accumulation has or still occurs. Coastal dune ridges are structures built up by sand blowing along or across the beach, into its upper part where you can find forms stabilised by vegetation.

Morphodynamic interactions in dunes are not well understood because of the chaotic relief of many coastal dunes defies simple description. The most important factors in dune development are aeolian processes, dune vegetation cover and winds. Dune plants stop sand being blown by wind from the beach. Big storm surges tend to deteriorate the coast and the nearby dune ridge environment also has a considerable influence on their dynamics. Newer dunes can also be destroyed by human activity. Settlement, tourism and business development can all have a negative impact through: overgrazing, deforestation, dune stabilisation, navigational improvements, water regulations, coastal protection and tourism growth (Carter 1980, Pye 1990, Piotrowska, Gos 1995, Nordstrom 2000).
Overgrazing and the deforestation of coastal areas may lead to new dune mobilisation (Nordstrom 2000). On the other hand dune stabilisation by planting vegetation may cause the spread of alien species (Nordstrom 2000, Piotrowska, Stasiak 1982). An increase in tourism and settlement activities offsets the coastal protection given by sea walls, groins, dykes, nourishment, vegetation planting etc. Dune management and seaside tourism development are the most recent main factors influencing the habitat destruction of dunes (Carter 1988, Pye 1990, Nordstrom 2000).

With an increasing danger to coastal environments steaming out from different sources, it is important to bear in mind how the present dune environment is developing under natural and human pressure. In Poland dunes cover almost $85 \%$ of the coast, which is strongly influenced by natural and anthropogenic factors. The coast is covered with different dune types and has recently shown variable, often unpredictable tendencies in its development.

The main aim of the work carried out by the author on coastal dunes in Poland is to outline dune environmental changes threatened by storms, winds, human activity and plants. Specifically to understand: the conditions that are causing dune ridges to grow or erode. This article summarises 15 years of investigation carried out on Polish coastal dunes with short descriptions of scientific observations in former work that has been carried out by other scientists. 


\section{Methods of the investigations}

The presented results are a summary of studies carried out on the Polish coast over the morphodynamics of coastal dunes (Polish dunes 2013) with an overview of Polish research of the dune coast. The entire study carried by the author involved measuring: (i) dune relief changes, (ii) vegetation dynamics, (iii) aeolian sand lithodynamics, (iv) human or animal influences, (v) storm surge impact, and (vi) wind impact. During field measurements geodesic tools were used as a leveller and 3D leveling using GPS RTK base. Some tests with ground laser scanning were conducted as well. The main measurements depended on the levelling of the beach and dune ridges and checking the distances among the forms that had built the coastal profile. The profiles were taken from the stabilised part of the dunes to the waterline. These measurements were repeated 2-3 times per year and also during storm surges. In total over 300 different profiles distributed throughout the Polish dune coast were studied. The longest series measured is located on the western part of the coast: the Świna Gate Sandbar (Labuz 2005b, 2009a, 2012a) and the Lake Jamno Sandbar - since 2001 (Eabuz 2003 b , 2012c), and other western sandbars and dune sections - since 2003 or 2004 (Musielak et al. 2005, Łabuz 2009b, 2012d, Łabuz, Osóch 2012, Łabuz, Skrzypiński 2012). On central and eastern part of the coast, detailed work has been conducted since 2010 excluding the Vistula Sandbar - since 2003 ( Labuz 2007b, 2012c). Some work is only focused on the aeolian processes, the most basic factor for dune development (Labuz 2003d, 2005a, 2005c, 2007d). During the field work we collected sand samples from the beach and dunes during different seasons to define the lithological dynamics of the sandy surfaces. Samples were also collected from the surface structures and from the layers in our excavations, mainly from washover fans - the marked storm surge impact ( abuz 2007c). Geological investigations were used for the observation of coastal dune development (Labuz, Olechnowicz 2004, Sydor et al. 2011, Sydor, Łabuz 2012). Observations on storm surges consisted of measuring the last surge range marked on the beach by debris and information about storm levels and wind fields that were taken by the Polish Maritime Office. Some detailed studies were conducted in relation to storm surge parameters and the erosion of dune ridges (Łabuz 2011, Łabuz, Kowalewska-Kalkowska 2011). The dune plant cover distribution and succession in relation to aeolian accumulation and dune growth was done as a part of certain studies (Łabuz 2002a, 2002b, 2003d, 2007c, 2007e, Łabuz, Grunewald 2007, Piotrowska et al. 2008). Research was also focused on the human impact on dune habitat ( $\mathrm{Labuz}$ 2003c, 2004, 2007b).

Data from the conducted studies are useful for different time scale comparisons as vectors, volumes or $3 \mathrm{D}$ relief maps. The presented studies cover almost $20 \%$ of all dunes on the Polish coast and is still ongoing. The idea of using simple research methods started from a need to move quickly in order to register changes caused by recent storm surges and heavy winds.

\section{Main factors and conditions of coastal-dune formation}

The balance of natural dune sediment is highly dependent on the geological movement of the land area in relation to the sea-level, the exposure of the coast to high speed winds, storm surges, the influence of vegetation, human activity, and coastal sediment granulation (e.g. Bird 1969, Psuty 1988, 1990).

The Polish coast is an aligned one and formed of only loose sediments. Extensive dune fields can be found on the Polish coastal plains that were formed after the glacial recession. Nowadays sandy dunes stretch over $85 \%$ of the $500 \mathrm{~km}$ long coastline (Labuz 2005a). It is a part of the southern Baltic shore (Fig. 1).

The shape of the Polish coastline and its exposure to predominant winds results in the coastal circulation of water which exerts a longshore sedimentary transport starting from middle coast (Koszalin Bay) in both direction: west and east, in the form of a so-called longshore stream (Rosa 1963, Pruszak, Zawadzka 2005, Zawadzka-Kahlau 2009). This process is complicated by other local longshore streams, which are orientated in the opposite direction (Baraniecki, Racinowski 1996). The situation is even further complicated by hydrotechnical structures and harbour breakwaters that were built in the 19th century.

The area of the Polish coastline is localised in moderate climate with $600-800 \mathrm{~mm}$ of precipitation per year and an average annual temperature $7-9^{\circ} \mathrm{C}$ (Miętus et al. 2004). During mild winters storm surges are common and during cold winters the coast can be covered with ice sheets (Miętus et al. 2004, Girjatowicz 2005). The springtime allows for dune development due to the increase in wind speed from direction oblique to the coast, Summer is calmer and during Autumn, stronger onshore winds reappear with offshore directions.

Polish well-urbanised coastal inland areas are endangered by an increasing sea level and increasing storm surges (Rotnicki, Borówka 1990). Most of the Polish coastal habitats including dunes are also threatened by human activities (Piotrowska, Stasiak 1982, Piotrowska 1995, Piotrowska, Gos 1995, Łabuz 2005a). However, human activity does not change dunes merely in a few places. There are still some places with natural dune coast that are protected or should be protected.

\section{Geological conditions associated with the coast}

The first observations describing the development of these coastal areas were done by German scientists in the early 1900's (Reinke 1911, Keilhack 1912, Hartnack 1926). The Polish sea-coast is built entirely of loose quaternary forms, most often fluvioglacial sands, post-glacial 


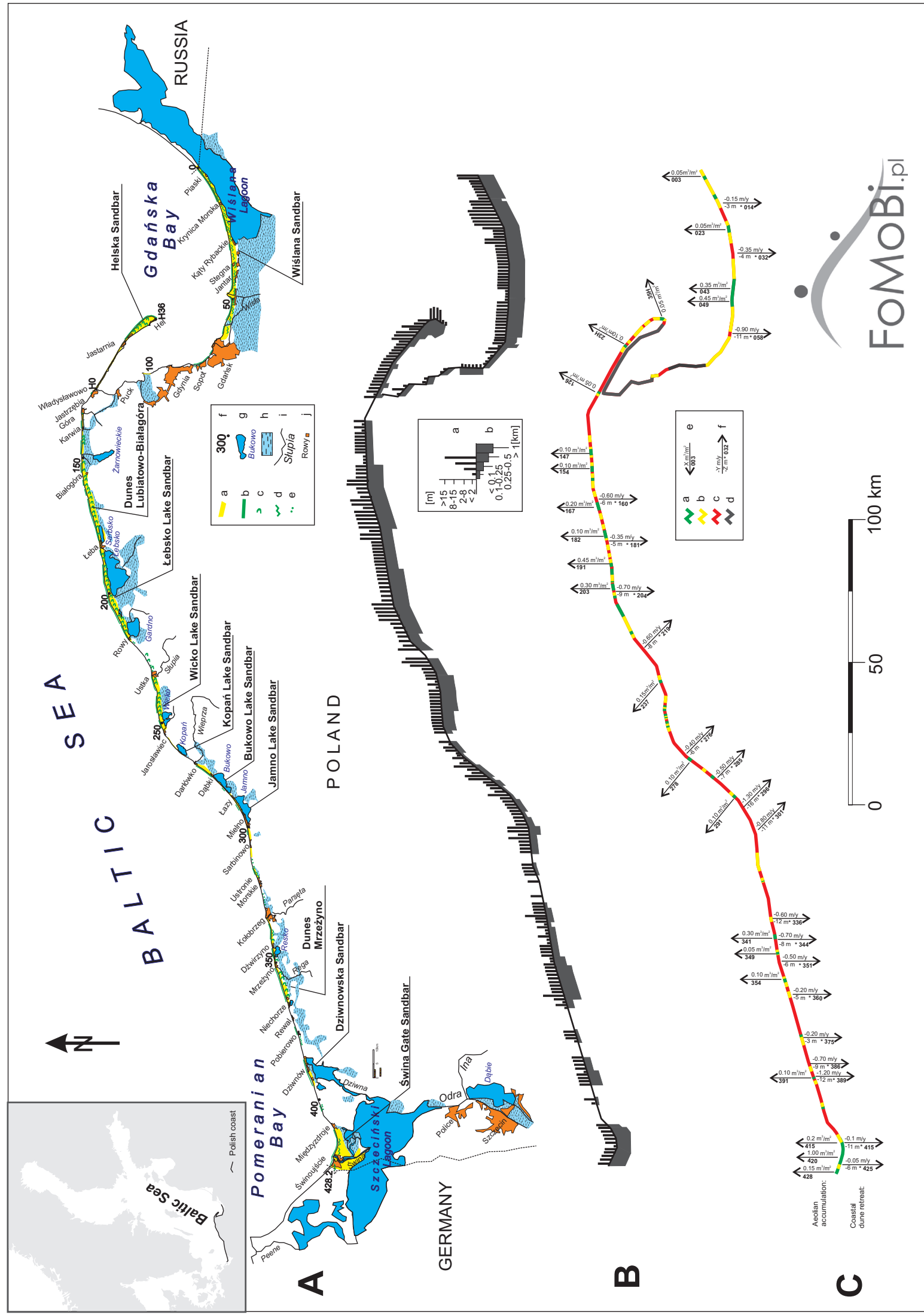

魚

学 
clays and organogenic structures (Mojski 2000, Tomczak 1995a). Their origin, coastal relief and geological structure is mainly related to last glacial period and fluctuations of Baltic Sea levels due to ice melt and its recession (Tomczak 1995a, Mojski 2000, Uścinowicz 2003 and others). Holocene transgression and glacio-isostatic movements of the crest led to the erosion of high cliff areas and the flooding of the some valleys. On the lower part of the coast with predominant marine and aeolian accumulated sand barriers, spits and peninsulas were created. These sandy coasts varied over time and slowly rebuilt as the sea entered low lands and certain bays.

The predominant erosion of land during sea transgression delivers sediment from the sea, which is deposited onshore and in accumulation areas, where sandbars and coastal dunes are then formed. Fluvioglacial sands form on inland coastal dunes and constitute a part of the Polish coast. Another source of material that constitutes dune coasts are numerous rivers that transport sediment to the sea. Also sandy shoals are another source of material that forms these present sandbars.

Discovering the original age of coastal dunes in Poland has been the aim of many studies - these formations started to develop after littorina transgression more or less 6 ka BP (Keilhack 1912, Hartnack 1926, Rosa 1963, Marsz 1966, Tobolski 1972, 1980, Borówka 1990, Tomczak 1995a, Mojski 1995, Fedorowicz et al. 2009, Reimann et al. 2010 and others). Different theories and research on specific sandbars reveal different stages of various dune development. The earliest Polish sandbars have been dated between 6 to $3 \mathrm{ka} \mathrm{BC}$, which is related to the sea level's recession (Rosa 1963, Tomczak 1995a, Uścinowicz 2003). The oldest dunes on the Vistula Sandbar - the so called brown dunes and low ridges - ended developing ca. 6 ka BP (Tomczak 1990, Fedorowicz et al. 2009). The oldest dated dunes arise from the Łebsko Lake Sandbar and originate from 5 to $4 \mathrm{ka} \mathrm{BP} \mathrm{(Rosa} \mathrm{1963,}$ Tobolski 1972, Borówka 1990). Some of the dunes from probably the youngest sandbars - the Świna Gate started developing around 3.5 ka BP (Rosa 1963, Prusinkiewicz, Noryśkiewicz 1966, Piotrowski 1999, Reimann et al. 2010), but the sand marine basement of the barrier is dated ca. 6.6 ka BP (Tomczak 1995b). The Hel Peninsula is a typical spit that developed on a large semimetal basement accumulated along a long drift from west to east (Pazdro 1948, Rosa 1963). Its development and shape is a continuous process, where parts were built around 5.6 ka BP and the wider promontory is dated to between 3 to $1.7 \mathrm{ka}$ BP (Tomczak 1995b). The oldest coastal dune ridges that now exist mainly around the back of the coast are $2-3,000$ years old. After certain periods of stabilization, accelerated progradation of dune fields arising from the Vistula and the Lebsko Lake Sandbars, occurred again during the "Little Ice Age" between 1550 and $1850 \mathrm{AD}$ (Rosa 1963, 1984, Rosa, Wypych 1980, Tobolski 1980, Borówka 1990, Rotnicki, Borówka 1995, Piotrowski 1999). Nowadays, along the coast, there are high dunes in areas that also have sea regression (Rosa 1963, Rosa,

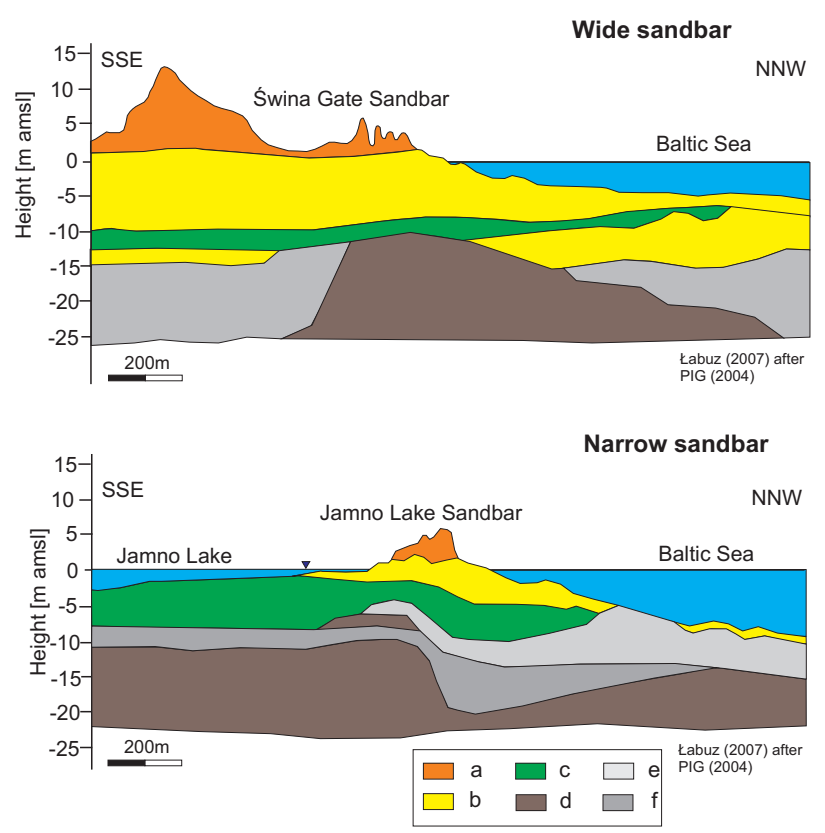

Fig. 2. Cross-sections of narrow and wide dune barriers types with description of geological structures (after PIG 2004)

$\mathrm{a}$ - dune sands, $\mathrm{b}$ - barrier sands, $\mathrm{c}$ - limnic, fluvial mud and peat, $\mathrm{d}$ - glacial tills, e - gluviolgacial and marine sand and gravel, $\mathrm{f}-$ reservoir muds

Wypych 1980). These have been built up along the coast in places where the most erosion prevails. In other places typical coastal ridges have developed. The development of coastal shifting sand sheets are caused by cooler and stormier climate conditions combined with human impact such as the deforestation of existing dune areas. Present foredune ridges have developed in a milder climate with positive sand budget on the coast with low plant effects. Due to the local geology, the sand balance budget and the output relief of the land different sandbars have developed (Fig. 2). Some of them are wider such as: Świna Gate, Łebsko-Gardno, Vistula, each with different types of dunes and other narrower with a single dune ridge and the accompanying low plains behind them, such as: Jamno, Bukowo Lakes Sandbars or the primarily eroded one such as: Kopań or Karwia Sandbars (Pawłowski 1922, Bohdziewicz 1963, Rosa 1963, 1984, Borówka 1990, Racinowski, Seul 1996, Zawadzka-Kahlau 1995, 1999, 2009, Łabuz 2005a).

\section{Material diameter}

The mineral composition and the diameter of sand that constitutes the areas of coastal and inland dunes are largely connected with lithologic features from the surrounding ground structure which is the main source of material (Rosa 1963, Rudowski 1986, Racinowski 1995, Baraniecki, Racinowski 1996, Wróblewski 2001, 2009, Łabuz, Olechnowicz 2004, Osadczuk 2004, Sydor et al. 2011), but is more or less all similar in grain size - so called monotony of grain size on Polish coast (Racinowski 1995). The diameter of sand that makes up the dunes along the Polish coast ranges from 0.10 to $0.50 \mathrm{~mm}$. The foredunes, that are building the coast in accumulative sections 
mainly consists of smaller sand from 0.16 to $0.25 \mathrm{~mm}$. It is a fine-grained sand with some medium-grain sand that has accumulated through strong winds. Above $90 \%$ of its composition is light quartz grain. The thicker sand in the foredune or upper beach areas appears along the periodically washed-out sections of the coast (Rudowski 1986, Wróblewski 2001, 2009, Łabuz 2009c). The finest grains of sand also constitute the youngest foredunes of the Polish sea-coast on the accumulative sections of the coast, and the thicker sand that forms the older foredunes are often eroded by the sea. On the Łebsko Lake Sandbar $50 \%$ of the sediment of the foredune ranges from 0.125 to $0.5 \mathrm{~mm}$ (Marsz 1966). The shifting dunes on this area are $85 \%$ fine-grained sand (Borówka 1980). The youngest dune ridges of the Świna Gate Sandbar are 74\% finegrained sand (Osadczuk 2004). The recent studies on present foredunes (www.fomobi.pl) indicate a 90\% share of deposits in diameter $0.16-0.35 \mathrm{~mm}(0.27 \mathrm{~mm}$ during Autumn to $0.2 \mathrm{~mm}$ during Spring in average).

\section{Wind conditions}

The most effective winds for sand accumulation on the dune ridge are angled obliquely to the beach (Bauer et al. 1990, Arens 1994). It was shown that wind strength plays a key role in sand volume transport (Bagnold 1941). Strong wind blowing of above $10 \mathrm{~ms}^{-1}$ are the most effective. Such winds are predominant during spring and winter and mainly during heavy storm surges. Wind regime data can be used to estimate daily, monthly, annual or long-term sand drift potentials and transport directions. This problem was the aim of studies carried out mainly on shifting dunes by the Łebsko Lake Sandbar (Borówka 1980) and its beaches (Borówka 1999, Borówka, Rotnicki 1999, Hildebrand-Radke 1999, Rotnicka 2011a, 2011b) and locally in other places (Mielczarski, Onoszko 1968, Niespodzińska 1980, Łabuz 2007d).

The Polish sea-coast is exposed mostly to W and SW winds (Nowaczyk 1986, Miętus et al. 2004). Winds with high velocity, above $10 \mathrm{~ms}^{-1}$, can be observed mostly during the colder parts of the year, occurring most frequently from NW, $\mathrm{N}$ and NE directions. The annual presence of these winds is about $10 \%$ in the western coast part (Table 1 ) and $15 \%$ in the eastern part. The annual probability of the occurrence of winds with a velocity above 15 $\mathrm{ms}^{-1}$ is about 6\% (Zeidler et al. 1995, Miętus et al. 2004). The heaviest storms, with strength between 10-12 on the Beaufort scale, are produced by NE winds, with a small annual $1 \%$ probability of occurrence, occurring usually in autumn and winter.

Most days with strong winds occur on the middle and eastern part of coast: Ustka to Hel towns, between No- vember and January. These winds cause dunes deflation and also storm surges that are a primary factor in dune erosion. The higher the wind velocity, the more sand that is transported (Bagnold 1941). The effectivity of sand transportation onto shifting dunes or beaches rises dramatically with velocity of the winds (Borówka 1980, Hildebrand-Radke 1999). A field investigation on $23^{\text {rd }}$ November 2004, during a storm surge recorded northwestern winds with strengths up to $22-23 \mathrm{~ms}^{-1}$ (ca $80 \mathrm{~km} / \mathrm{h}$ ), that produced very heavy and long beach sand transportation (Łabuz, 2007d). The most intense sand transport during an occurrence of oblique to the coast high-speed winds $\left(>8-10 \mathrm{~ms}^{-1}\right)$ was observed on the lower and middle parts of the beach, where accumulation occurred on the upper beach covered in vegetation (Rotnicka 2011a). Sand transport deceleration has risen from the middle beach area, through the upper areas to the foredunes (Hildebrand-Radke 1999, Rotnicka 2011a, 2011b). On the beach over $30-50 \%$ of sand is transported towards the middle section, when winds are blowing along the beach. On the upper beach relief, obstacles such as embryo dunes covered with grass leads to its accumulation (Labuz 2007a, 2007b). The wider the beach, the more sand that can be transported by winds onto the foredunes. Approximately $10-15 \%$ of transported sand may be accumulated on foredune when the wind is strong enough to carry material from the beach to its ridge (Hesp 1981, Psuty 1988, Goldsmith et al. 1990, Arens 1994). That's why the growth of the foredunes is slow and occurs mainly when strong winds play a role in the aeolian processes.

\section{Oscillations in the sea-levels and waves}

We recorded two types of sea level rise: annual oscillations caused by weather conditions and long-term slow growth, recorded in relation to rising ocean levels. The mean sea level on the western sea-coast in Świnoujście is $497 \mathrm{~cm}$ and is lower than 'absolute zero' in relation to Amsterdam's $500 \mathrm{~cm}$. The level increases eastwards, up to $500 \mathrm{~cm}$ in Kołobrzeg and Łeba and then up to $504 \mathrm{~cm}$ in Gdańsk (Zeidler et al. 1995). Oscillations in sea-levels are associated with the oscillations of pressure systems and the formation of wave-generating winds (Wróblewski 1975, 1998, Miętus et al. 2004, Sztobryn et al. 2005, Pruszak, Zawadzka 2005). The amplitude of the registered sea-level oscillations reaches above $3.2 \mathrm{~m}$ in Świnoujście and $3.4 \mathrm{~m}$ in Kołobrzeg (Dziadziuszko, Jednorał 1988). Waves depend on the velocity and direction of the winds and the duration of their occurrence (Wróblewski 1975, Sztobryn et al. 2005). Prolonged high velocity winds, blowing from the open sea, generate storm waves that are accompanied by coastal water surges. Most

Table 1. The frequency of winds (\%) in Świnoujście

\begin{tabular}{ccrrrrrrrrl}
\hline Years & N & \multicolumn{1}{c}{ NE } & \multicolumn{1}{c}{ E } & \multicolumn{1}{c}{ SE } & \multicolumn{1}{c}{ S } & SW & W & NW & Calm & Source \\
\hline $1876-1900$ & 9.25 & 11.50 & 7.75 & 11.75 & 12.50 & 16.00 & 17.00 & 10.50 & 3.75 & Hartnack 1926 \\
\hline $1961-1995$ & 7.63 & 9.68 & 8.91 & 8.46 & 16.29 & 18.49 & 20.25 & 6.72 & 3.57 & Łabuz 2005a after IMGW \\
\hline $2001-2011$ & 6.06 & 7.54 & 10.25 & 11.20 & 14.62 & 22.44 & 17.41 & 7.43 & 3.05 & Maritime Office \\
\hline
\end{tabular}




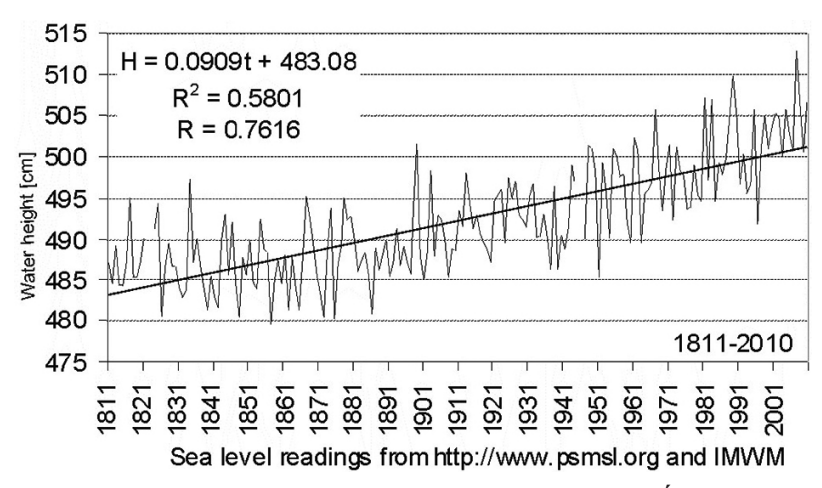

Fig. 3. Sea level changes and growth trend in Świnoujście (Kowalewska-Kalkowska \& Marks 2011). Sea level readings from www.psmsl.org and IMWM

storm surges occur in autumn and winter; on the western sea-coast most storms above 6 on the Beaufort scale are the result of $\mathrm{N}$ winds $55 \%$, then NW $31 \%$ and NE $14 \%$ (Miętus et al. 2004).

The longest observations of Baltic Sea level changes in Świnoujście (Fig. 3) indicate an increase trend of $0.1 \mathrm{~cm} / \mathrm{y}$ (Kalkowska-Kowalewska, Marks 2011). Sea level changes are one of the major factors in shaping the beach - a transferring zone of hydrodynamic influence throughout the beach's profile (Musielak 1989). The highest sea level on the Polish coast, up to $2 \mathrm{~m}$ above mean sea level (a.m.s.1.): $696 \mathrm{~cm}$ was observed in Świnoujście in February 1874 (Zeidler et al. 1995). On the South Baltic coast the sea level during a storm may rise up to 1.5 - 2 m a.m.s.l. (Dziadziuszko, Jednorał 1988), but water inflows on the land reach $3.5 \mathrm{~m}$ a.m.s.l. Each storm surge noticed on Baltic coast seems to have a bigger impact, because the coast relief does not recover. The scale of coastline erosion and retreat depends both on the sea surge height and its duration. Average retreat velocity is $0.1 \mathrm{~m}$ year $^{-1}$ over the last 100 years, and $0.5 \mathrm{~m} /$ year from 1960 to 1983 (Zawadzka-Kahlau 1999, Pruszak, Zawadzka 2008). Nowadays, the average coastal land withdrawal on the western Polish coast is $0.9 \mathrm{~m} /$ year and after one storm event it may be even as high as 5-8 m (Łabuz, 2009b, Łabuz, Kowalewska-Kalkowska 2011). Only land protected by beaches higher than $3.5 \mathrm{~m}$ is more or less safe (Fig. 4). The most catastrophic sea surges are observed with a sea level $1 \mathrm{~m}$ above mean (a.m.s.1.), when water floods the beach and overflows over the dune depressions and low ridges up to $3.5 \mathrm{~m}$ a.m.s.l. All relief forms below this level are abraded, and dune ridges on the beach hinterland are subject to regression (Łabuz 2005a, 2009b). Over the last 10 years, the Polish sea-coast has been subject to several storms with a sea level 1 meter above the mean level, which leads to coastal dune erosion (Łabuz 2009b, 2011). The most costly storms for nature and human infrastructure were in November 1995, October 2004, 2006 and 2009 and January 2012 (Table 2, Fig. 5). Erosion was significant in certain coastal towns, where heavy coastal measures have been built or yearly artificial beach nourishement is the only the way to more or less protect the coastline. The washover fans, known from Hel Peninsula (Wróblewski 2001) or Świna Gate Sandbar (Labuz 2009c) are forms created by water inflow on the low land areas and mark the range of storm
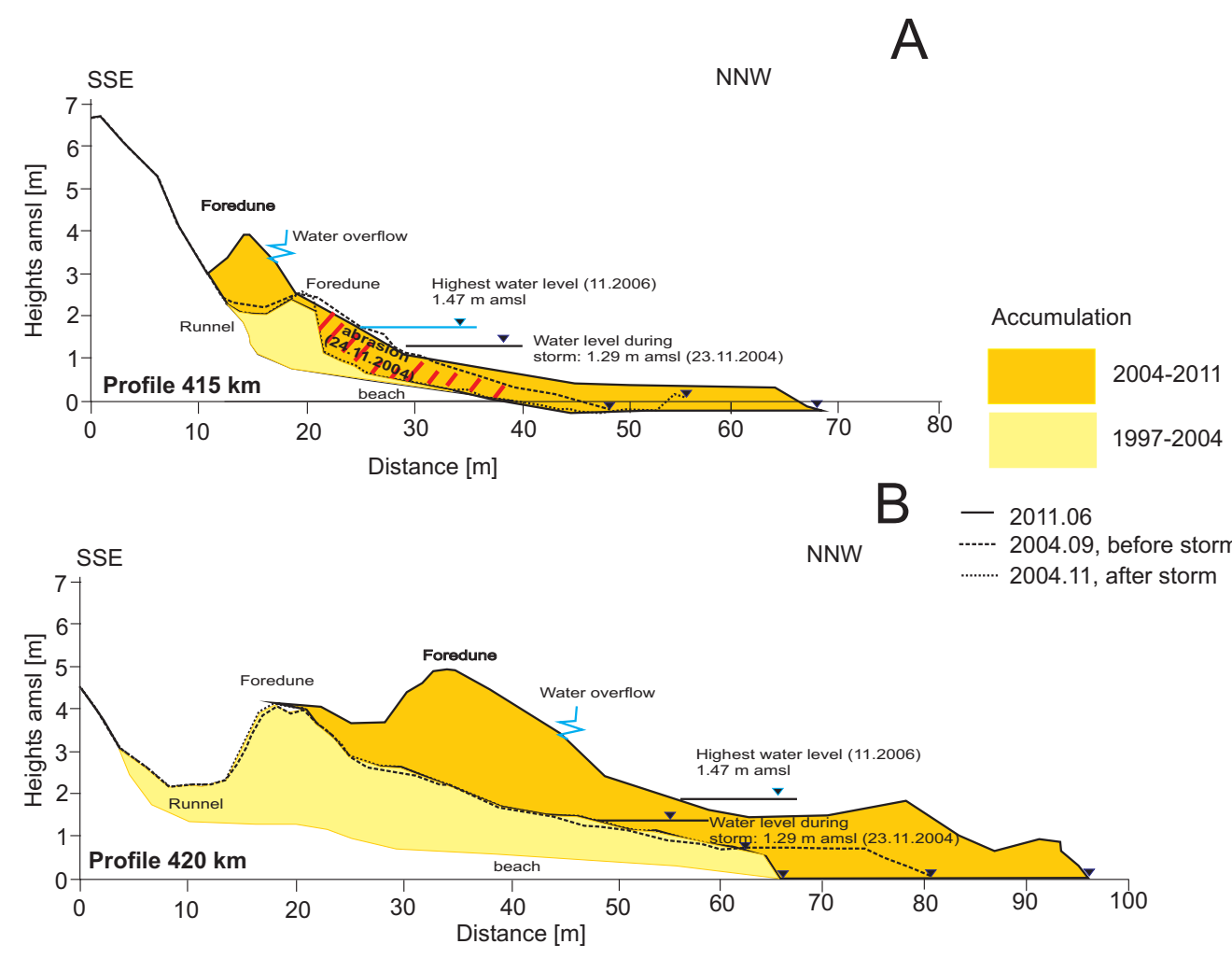

Fig. 4. The influence of sea level rise during storm surge (example of 23 November 2004 storm) on dune morphodynamics (till 2011) related to beach height above sea level, Świna Gate Sandbar (Labuz 2009a, completed)

A - profile similar to reflective: low beach, high abrasion of the foredune, B - profile similar to dissipative: high beach, accumulation prevails 
Table 2. The list of storm surges with water level $1 \mathrm{~m}$ above mean one (amsl) noted on west Polish coast (Świnoujście 2001-2010, data from Maritime Office), (Labuz 2005a, 2012e, completed) in comparison with land erosion rate on examined field profile $1 \mathrm{~m}$ width (416 $\mathrm{km}$ of coast)

\begin{tabular}{|c|c|c|c|c|c|c|c|}
\hline & Date & Storn & rrges & & & Dun & rosion \\
\hline Year & Day Month & $\begin{array}{l}\text { Max. sea level } \\
\text { [m a.m.s.1.] }\end{array}$ & $\begin{array}{c}\text { Sea waving } \\
\text { [Bft] }\end{array}$ & Direction & $\begin{array}{c}\text { Velocity } \\
{\left[\mathrm{ms}^{-1}\right]}\end{array}$ & $\begin{array}{c}\text { Foot retreat } \\
{[\mathrm{m}]}\end{array}$ & $\begin{array}{l}\text { Sand volume } \\
\text { per } 1 \mathrm{~m} \text { profile } \\
\text { width }\left[\mathrm{m}^{2}\right]\end{array}$ \\
\hline 2001 & 8-11 Nov & 0.96 & 6 & $\mathrm{~N}$ & $11-13$ & & \\
\hline 2001 & 15-17 Nov & 0.97 & 6 & NW & $11-14$ & & \\
\hline 2001 & 22-25 Nov & 0.98 & 7 & NW & $13-15$ & 3.60 & 7.34 \\
\hline 2002 & 1-3 Jan & 1.04 & $7(9)$ & NNE & $13-15$ & & \\
\hline 2002 & 19-22 Feb & 1.42 & 7 & $\mathrm{NE}$ & $14-16$ & 4.50 & 2.72 \\
\hline 2003 & 6-7 Dec & 1.04 & 7 & $\mathrm{~N}$ & $14-16$ & 3.00 & 0.25 \\
\hline 2003 & 21-25 Dec & 1.01 & 8 & NW-N & $16-18$ & No data & No data \\
\hline 2004 & $22-25 \mathrm{Nov}$ & 1.29 & $10-12$ & NW & $17-20$ & 7.00 & 5.18 \\
\hline 2006 & 31 Oct -4 Nov & 1.47 & $8-9(12)$ & $\mathrm{N}$ & $16-20$ & 1.90 & 4.00 \\
\hline 2007 & 18-20 Jan & 1.40 & 10 & NW & $15-19$ & & \\
\hline 2007 & 21-28 Jan & 1.25 & 7 & NW & $14-16$ & 5.00 & 12.65 \\
\hline 2008 & 21-23 Mar & 1.04 & 7 & $\mathrm{NE}$ & $12-15$ & 1.00 & 1.10 \\
\hline 2009 & 13-16 Oct & 1.33 & $8-9$ & NNE & $15-18$ & 3.00 & 1.29 \\
\hline 2010 & $15 \mathrm{Dec}$ & 1.00 & 6 & $\mathrm{NNE}$ & $14-16$ & 1.50 & 0.76 \\
\hline 2011 & $17 \mathrm{Dec}$ & 1.00 & $6-7$ & NW & $15-17$ & 1.00 & 1.40 \\
\hline 2012 & 6 Jan & 1.00 & 7 & NNW & $13-15$ & 250 & 550 \\
\hline 2012 & 14 Jan & 1.30 & 10 & NNW-N & $14-17$ & 2.50 & 5.50 \\
\hline
\end{tabular}

surge threats on coastal land. In many other places such as: Karwia Sandbar, dunes on Wicko, Gardno and Łebsko Lakes Sandbars, the narrow sandy belt of Kopań, Jamno, Bukowo or low lying areas of Sobieszewska Island on the Vistula Sandbar are in danger due to storm surge flooding (Messyńska Sandbar). This has also been the subject of recent studies in Poland, where well-urbanised areas on coastal lowlands are endangered by flooding (Rotnicki, Borówka 1990).

\section{Ice jams}

Ice jams that appear in winter (Girjatowicz 2005) are another factor of coastal dune erosion. An ice jams in the mouth of a river may also cause flooding in the surrounding land areas. Ice pushed ashore by waves may erode the beach and land relief, as well as destroy the local infrastructure. It can damage piers as well as used coastal protection structures. The ice cover defaulting on a beach in the spring prevents the accumulation of sediment by wind and reconstruction after the fall and winter storm periods. The longer period of ice cover on beach the less accumulation takes place. The coastal ice simultaneously destroys the relief and stops its rebuilding. Ice jams with storm surges may cause coastal dune retreat and are respond for beach lowering. Such beach is more endangered by flooding. This was observed on the Polish coast in February - March 2003, 2006, 2010 and 2011 (Fig. 6).

\section{Biogenic conditions}

The development and maintenance of dunes is enhanced by pioneer vegetation, which traps the sand blown onto the upper beach and dunes. On Polish beaches, the first plants appear within reach of wave inflow, with deposits organic matter that provides the sand with nutrients (Celiński, Piotrowska 1965, Łabuz, Grunewald 2007). Most often, this is an accumulation of shells, algae, fragments of wood, roots, stems and the seeds of plants that come from washed away sections of the coast - referred to in Poland as kidzina detritus. In this zone there are three halophyte species (Celiński, Piotrowska 1965, Łabuz 2002a, 2003d). These are: Cakile maritima, Salsola kali and Honckenya peploides. On the beaches near seaside towns and along the beaches often washed away by the sea, halophytes often do not take root (Labuz 2002b, 2003a). Among the halophytes, Honckenya peploides (sea sandwort) is the most significant plant causing aeolian accumulation on Polish beaches. It has a height of several centimeters, with a long and extensive root system that attains a $2 \mathrm{~m}$ depth. It is the first plant on the upper beach that stops sand and helps build up embryo dunes with heights of up to $0.5-1.0 \mathrm{~m}$ (Labuz 2002a). On dune tops, where the accumulation is more intensive, this plant does not appear. The first grasses on the upper beach are the main obstacles for blown-in sand. Observations show that grass clumps of up to $1 \mathrm{~m}$ in height can stop winds with speed below $8 \mathrm{~m} / \mathrm{s}$ which leads to fast sand accumulation (Łabuz 2009a).

In the upper part of a beach, where wave inflow occurs only during strong autumnal-winter storms, there are pioneer dune grasses (Table 3): Elymo-Ammophiletum communities: european beach-grass Ammophila arenar$i a$, lyme-grass Elymus arenarius, the sandy variety of red fescue Festuca rubra ssp. arenaria, and hybrid grass $X$ Calammophila baltica (formerly named Ammophila baltica). These are plants of the next phase in the succession of movable sands at the tops of the youngest white coastal 

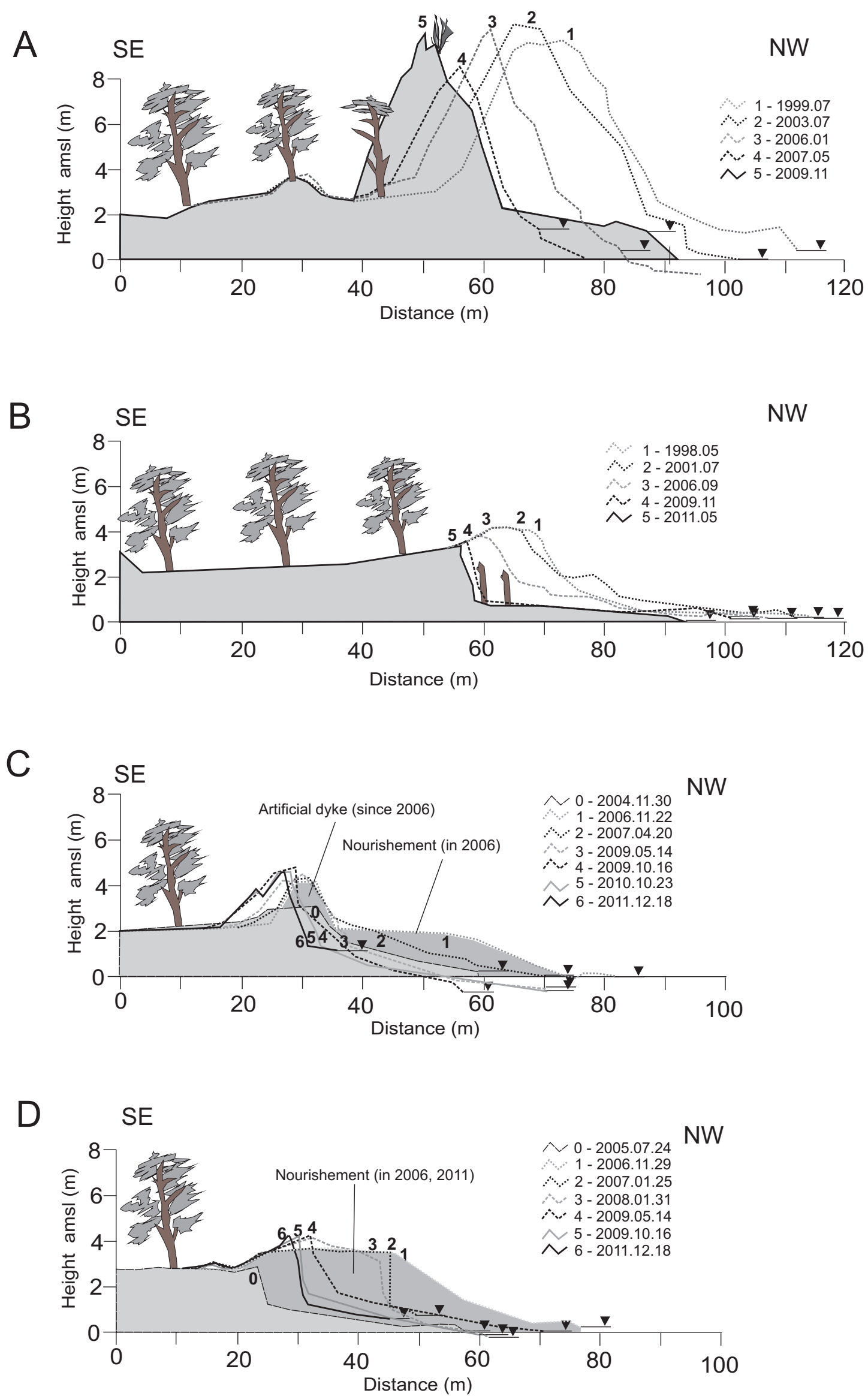

Fig. 5. The highest rates of coast retreat caused by storm surges

A - shifting inland foredune, B - washed away low dune coast, C - eroded artificial dyke and nourished beach, D - eroded artificial beach/dune feature on low coast 

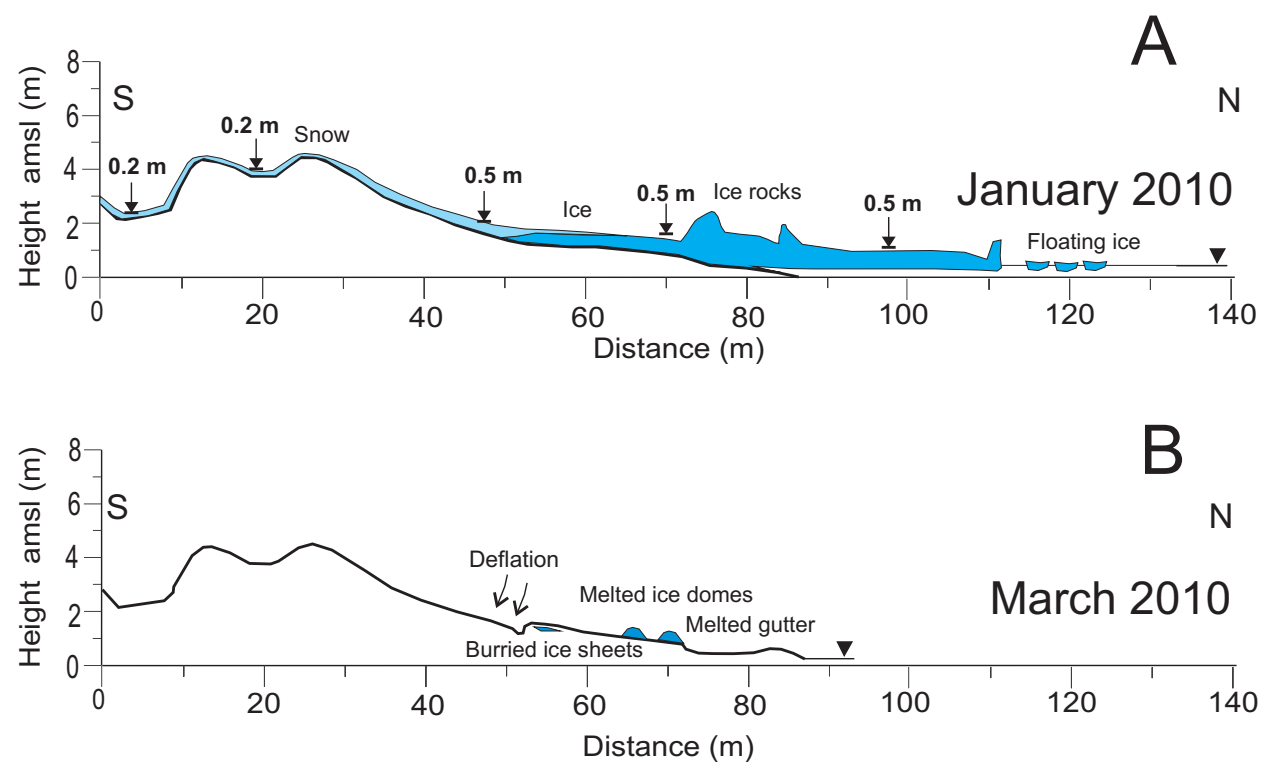

Fig. 6. Coastal dune profile influenced by ice in cold period A - winter profile, $\mathrm{B}$ - spring profile

Table 3. Plant species occurring on typical accumulative beach, covering the initial foredune field (Łabuz 2003d)

\begin{tabular}{|c|c|c|c|c|c|c|}
\hline \multirow{2}{*}{ Plant species } & \multicolumn{3}{|c|}{ Dune hillocks } & \multicolumn{3}{|c|}{ Lower deflation areas, blowouts } \\
\hline & Very dense & Dense & Rare & Very dense & Dense & Rare \\
\hline Honckenya peploides & + & & & + & & \\
\hline X Calammophila baltica & + & & & & + & \\
\hline Ammophila arenaria & + & & & & & + \\
\hline Leymus arenarius & + & & & & & + \\
\hline Festuca rubra ssp. arenaria & & + & & & + & \\
\hline Cakile maritima & & + & & & + & \\
\hline Salsola kali & & + & & & + & \\
\hline Elymus farctus (Agropyron junceum) & & $+*$ & & & & + \\
\hline Petesities spurius & & & + & & & + \\
\hline
\end{tabular}

* only Świna Gate Sandbar

dunes - foredunes (Piotrowska, Celiński 1965, Piotrowska, Gos 1995, Łabuz, Grunewald 2007). This habitat is the main cause in foredune development and its permanent growth (Fig. 7, Table 4). Spring time is the period when coastal dunes grow: strong winds lead to aeolian transportation and plant appearance are the combination of factors causing dune grow period at a rate of $0.2-0.5$ $\mathrm{m}$ per square meter of the ridge during the March-June. These plants may stop 50\% of the sand blown from the lower beach onto the upper beach thus causing foredune development each 4-5 years - as on the Świna Gate Sandbar (Łabuz 2009a).

On the more stable grounds of yellow dunes, where the accumulation is not as intense, one can find xerophilous plants of the Helichryso-Jasionetum communities (Piotrowska, Celiński 1965, Piotrowska, Stasiak 1982, Łabuz, Grunewald 2007). The main species in this community are Helichrysum arenarium, Corynephorus canescens, Jasione montana, Hieracium umbellatum, Artemisia campestris var. dunense and numerous mosses and lichens along with willow species shrubs (Table 5). In this community is also
Eryngium maritimum - symbolic of Polish dunes. Unfortunately, due to erosion and the afforestation of dunes, its habitat is shrinking. At present, it is most commonly visible on the Vistula Sandbar and dunes of the central coast Bukowo Lake-Kopań Lake (Labuz 2007c). The last stage of vegetation succession on the coastal dunes is represented by forests that grow on brown dunes that have a fully developed profile of podsol soils. These are various types of coastal pine forests Empetro nigri-Pinetum (Piotrowska 1995). Along the low and wet backgrounds of dunes are forests that are characteristic for moist areas - with a great number of plants and broadleaf trees.

In coastal towns, plants that grow on dunes are usually affected by human activity: mainly deforestation and trampling of vascular plants. This is causing relief destabilization that lead to deflation processes. Afforestation in the $19^{\text {th }}$ century of almost all shifting dunes in Poland lead to their stabilization. Nowadays only $15 \%$ of a typical coast with foredunes has well developed plant succession stages and over $35 \%$ is in the erosion phase with encroaching forests on the nearest ridges to the beach. 

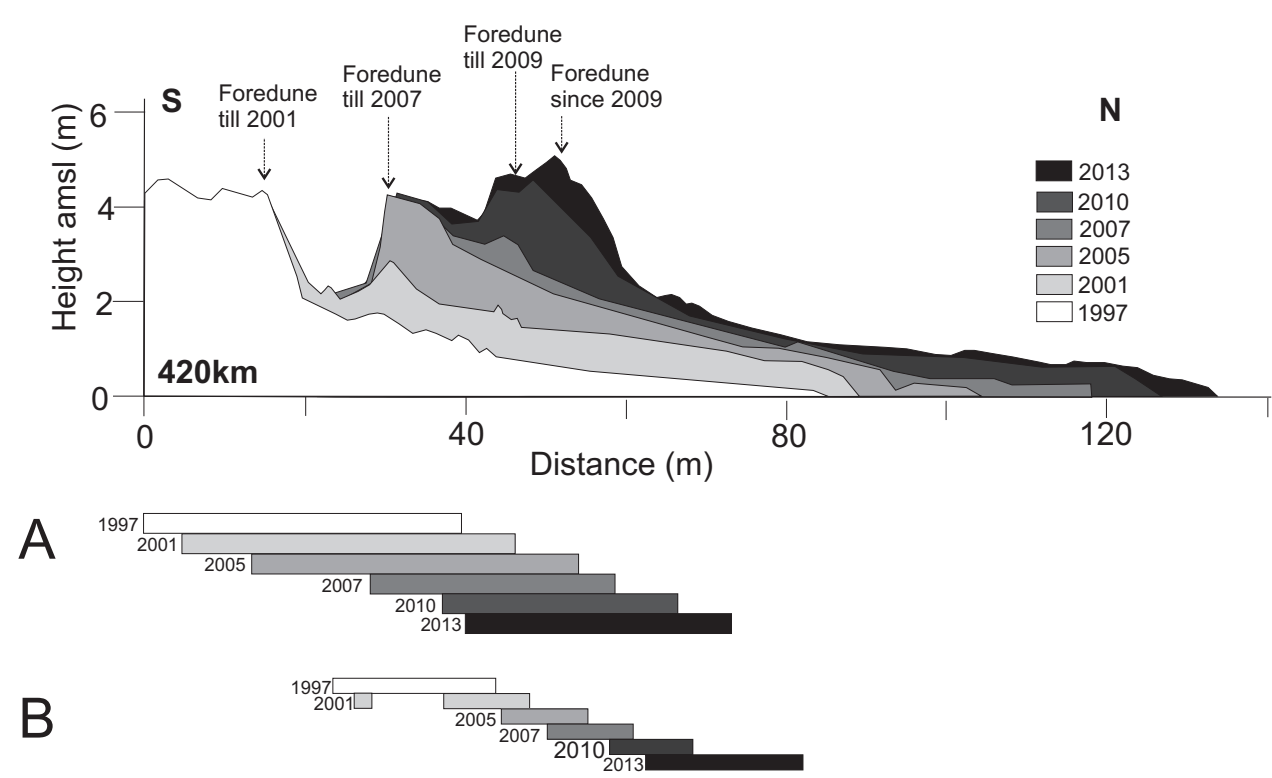

Fig. 7. The increase of pioneer plants habitats related to coastal progradation and foredune formation (Swina Gate Sandbar, $420 \mathrm{~km}$ ) $\mathrm{A}$ - pioneer grasses on dunes, $\mathrm{B}$ - pioneer habitats on beach

\section{Human development impact}

In coastal towns, the types of human impact and their intensity are diverse (Pye 1990, Nordstrom 2000). In Poland their intensification depends first of all on the size and number of functions in a given locality. Historically, buildings in these towns have been situated mostly on the coastal lowlands close to the mouths of rivers, from where sea access is easier than from the steep and high moraine sea-coasts. The mouths of all Pomeranian rivers and their nearby coasts are covered by port facilities, sea-harbours, tourist accommodations and other dwellings (Polish dunes 2013).

In order to attract tourists and maximize profits, buildings are increasingly often located at the top of the first coastal-dune and seasonally on the upper beach (Łabuz 2003a, 2003c). The largest tourist investments are made in large localities, that have long served as seaside resorts and

Table 4. Characteristic of the habitats (Elymo-Ammophiletum community) of the youngest dune ridges - foredune (Labuz \& Grunewald 2007)

\begin{tabular}{lll}
\hline $\begin{array}{l}\text { Habitat } \\
\text { description }\end{array}$ & $\begin{array}{l}\text { Mechanical stress from moving sand (sand burying), } \\
\text { sand accumulation, loose sand, striking by sand grains }\end{array}$ & $\begin{array}{l}\text { Mechanical stress from moving sand (sand burying), } \\
\text { larger grain sizes (too heavy to be moved by the wind), } \\
\text { decrease of sand }\end{array}$ \\
\hline Typical plants & $\begin{array}{l}\text { X Calammophila baltica, Leymus arenarius, Ammophila } \\
\text { arenaria, Honckenya peploides }\end{array}$ & $\begin{array}{l}\text { Festuca rubra ssp. arenaria, Corynephorus canescens, } \\
\text { Festuca rubra ssp. moving sand (sand burning), sand } \\
\text { accumulation, loose sand, dryy drye phyto-biodiversity } \\
\text { of disturbed and und }\end{array}$ \\
\hline
\end{tabular}

Table 5. Characteristic of the habitats (Helichryso-Jasionetum communities) of the older dune ridges covered by psammophilous meadow (Łabuz \& Grunewald 2007)

\begin{tabular}{|c|c|c|c|c|}
\hline & \multicolumn{2}{|c|}{ Open habitats } & \multicolumn{2}{|c|}{ Habitats under trees } \\
\hline & Open sandy areas & Covered sand & Pine tree shadow & Willow shrub shadow \\
\hline $\begin{array}{l}\text { Habitat } \\
\text { description }\end{array}$ & $\begin{array}{l}\text { Very warm and dry with } \\
\text { some moving sand, gene- } \\
\text { rally more exposed sites on } \\
\text { ridges }\end{array}$ & $\begin{array}{l}\text { Very warm and dry without } \\
\text { moving sand, generally } \\
\text { more exposed sites on } \\
\text { ridges }\end{array}$ & $\begin{array}{l}\text { Generally northern slopes } \\
\text { and depressions (but also } \\
\text { on the top and south side } \\
\text { of older dunes) }\end{array}$ & $\begin{array}{l}\text { Northern slopes and de- } \\
\text { pressions (but also on the } \\
\text { top and south side of older } \\
\text { dunes) }\end{array}$ \\
\hline Typical plants & $\begin{array}{l}\text { Corynephorus canescens, } \\
\text { Ceratodon purpureus } \\
\text { (moss), }\end{array}$ & $\begin{array}{l}\text { Helichrysum arenarium, } \\
\text { Corynephorus canescens, } \\
\text { Helichrysum arenarium, } \\
\text { Jasione Montana, Sedum } \\
\text { acre and different mosses } \\
\text { and lichens }\end{array}$ & $\begin{array}{l}\text { Pinus sylvestris, Poly- } \\
\text { podium vulgare, Dicra- } \\
\text { num scoparium (moss), } \\
\text { Deschampsia flexuosa, } \\
\text { Epipactis atrorubens }\end{array}$ & $\begin{array}{l}\text { Salix spec., Polypodium } \\
\text { vulgare, Dicranum scopa- } \\
\text { rium (moss), Deschampsia } \\
\text { flexuosa, Epipactis atroru- } \\
\text { bens, Trifolium arvense, } \\
\text { Pyrola minor, } \\
\text { Brachithe cium rutabulum } \\
\text { (moss) }\end{array}$ \\
\hline
\end{tabular}


economic centers: Świnoujście, Kołobrzeg, Ustka, Tricity. Beside a dense distribution of private quarters and towering hotels, these dunes are often covered by promenades and coastal terraces (Dziwnów, Kołobrzeg, Sarbinowo, Mielno, Ustka), dissected by piers (Międzyzdroje, Kołobrzeg, Sopot), and also covered by numerous cafes and hotels with views of the sea (Międzyzdroje, Kołobrzeg, Sarbinowo, Mielno, Darłówko, Ustka, Łeba, Sopot). With this large concentration of buildings, the entire sea-coast within the aforementioned localities is devoid of natural scenery (Kołobrzeg, Ustka, Mielno, Gdańsk-Sopot). Nowadays, due to economical development, new locations have been earmarked for the construction of apartments and luxury hotels (mostly in each coastal resort).

Recently on the intensely ravaged sections of the coastline, the dunes were destroyed altogether (Dziwnów, Niechorze, Kołobrzeg, Darłówko, Mielno, Ustka). Only on the Vistula Sandbar the buildings are situated further back from the shore - on lagoon banks (Labuz 2007b). Another problem are the often illegal passageways to the beach through the dune ridges. During windy periods, large amounts of sand are moved from the beach through these passages (i.e. during wind action with speed $8 \mathrm{~m} / \mathrm{s}$ during 5 minutes about $12 \mathrm{~g}$ of sand was blown across a typical path in Dźwirzyno, whereas across a foredune only $0.8 \mathrm{~g}$ was blown).

On sections of the coast that are situated far from coastal towns or in strategic points of along the coast, there are also military buildings and structures. Often inaccessible from land, they are located in the background of the coastal dunes and enclosed by fences and / or walls. Therefore it was not possible to determine the exact type of buildings and objects and their influence on the dunes. Since the 1990s, the military has abandoned some of these installations (Lake Jamno Sandbar, Hel peninsula) and some have been re-developed for tourist purposes (Lake Resko and Lake Jamno Sandbar). These activities contribute to the a rapid increase in sections that become intensely used by tourists and subjected to strong anthropopression.

\section{Coastal protection and nature conservation}

At present, various solutions have been proposed for the protection of the coast. Since the end of World War II, two types of coastal protection have been applied: 1st a hydrotechnical engineering that strongly interferes with the dune coast ecosystem and 2nd a biotechnical protection based on the fixation of dunes using vegetation: forest and dune grasses, as well as fascine fences.

Coastal protection in Poland falls under the responsibility of three units of the Maritime Office that are financed by the state. Coastal protection can also be performed by local authorities, communities and private investors, through approval of the Maritime Office.

The low-lying areas of the sandbar coast is threatened by flooding due to the increases in the sea levels and high storm surges which erode the dune ridges. On the Polish sea coast these threatened areas include: the lower sandbar parts of Wolin and Uznam (parts of the Świna Gate Sandbar), the Dziwnów Sandbar, the valley of the Odra together with the coasts of the Szczecin Lagoon and Lake Dąbie, the low-lying outlets of the Rega, Wieprza, Słupia and Łeba rivers, sandbars and coastal-lowlands of coastal lakes, e.g. Livia Łuża, Resko, Jamno, Bukowo, Kopań, Wicko, Gardno, marshy lowlands around the area of Kołobrzeg, Karwia, the Puck Lagoon coast on Hel Peninsula and the low-lying parts of the Vistula delta, and the outlets of rivers and water-currents of Gdańsk Bay (Rotnicki, Borówka 1990). On these threatened sections of the coast, buildings and infrastructure are protected by numerous coastal protection services (Basiński et al. 1993, Dubrawski, Zawadzka 2006). The protection concerns mostly the area of coastal towns with the need for protection at a considerable investment. An example of the greatest number of coastal protection activities and potential threats is the city of Kołobrzeg situated up to $2 \mathrm{~m}$ a.m.s.l. and surrounded by marshes and wet fields. From the sea side, it is only protected by a narrow dune in a vestigial form and by a low dyke built of clay with a height of $3.5 \mathrm{~m}$. Since 2003, Polish coastal protection has been realized its National Strategy based on legalized act (Cieślak 1995). In view of the fact that the state does not have enough money to continue these programs, in 2007 they began using funding from the EU from their Infrastructure and Environment programs.

Hydrotechnical engineering includes concrete-bands and coatings with stones and tetrapods located at the foot of the dunes on the beach, wooden piles thrust into the shallow shoreface that go out to $200 \mathrm{~m}$ from the coast. The length of coast protected using these techniques is more than $130 \mathrm{~km}$ (i.e. about $25 \%$ of the whole coastline). Among them, piles cover $36 \%$ of the coast, bands 25\%, bands and piles 16\% (Dubrawski, Zawadzka-Kahlau 2006). For the last 5 years, new coastal treatments have been completed, mainly concrete bands covering eroded dunes or the lower parts of coast (Lake Kopan Sandbar, low coast on Karwia Snadbar, Westerplatte - bank of Vistula river in Gdańsk). New ones are under construction or are being prepared for integration (Kopań Lake Sandbar, area of Kołobrzeg, Bay between Ustka and Rowy, Wicko Lake Sandbar, mouth of Lake Jamno outlet, end of Hel promontory near Hel town).

There are also numerous biotechnical activities connected with the planting of selected plant species (mainly Ammophila sp.). In order to stabilize the eroding ridges or the lowland the dune tops were afforested, despite the loss of already rare communities of psammophilous grasses. Nowadays due to attitude changes this process is no longer carried out. The extension of the slope and the base of the coastal ridge is obtained by planting arenaria grasses along with the construction of fascine fences as well as coverage of the slopes using dry twigs.

In the mid-1980s, a method of artificial sand nourishement was introduced in Poland (Dubrawski, Zawadzka-Kahlau 2006). These actions were forced by an 
increasing deficit of material and the failure of hydrotechnical devices to protect the coast (firstly on Hel Spit). The material for artificial sand nourishement is obtained directly from the sea bottom, 2-5 km from the coast. Most frequently, this method is used to protect short beach sections, 0.5 to $1 \mathrm{~km}$ long in touristic towns and villages. For a long time this method was used on the Hel Peninsula, where the base of the peninsula from Władysławowo to Jurata (over $20 \mathrm{~km}$ ) had been strongly eroded (Furmańczyk 1995) and washed over by storm surges. Over the past 10 years, the method also served to protect coasts in many seaside towns, such as Łeba, Ustka, Kołobrzeg, Mrzeżyno, Dźwirzyno, Niechorze, where nourishement is being perform every 2-3 years. Observations showed that after a single strong storm surge, the entire artificially built beach had been washed away where its height was lower than the water level and over-flow: Dziwnów or Kołobrzeg (Łabuz 2009b, 2012d). Besides beach nourishement, coastal protection services reconstruct dune ridges and build new floodbanks (Kopań Lake Sandbar, Dźwirzyno, Mrzeżyno towns).

Coastal protection in Poland has a purely economic significance. It is understood in terms of the protection of human dwellings, regardless of the interference to the environment. Since the 2007 Natura 2000 program, specimen and rich habitat protection has been ongoing. Therefore coastal infrastructure development and protection measures are under special supervision. The protection of coastal dune habitats has been mainly successfully carried out in the Słowiński National Park on Lake Gardno and Łebsko Sandbar. Also on the Vistula Sandbar there are natural reserves that strictly protect birds. Along other parts of the Polish coast we have two landscape parks and several Natura 2000 areas that do not have a completely established protection status. In other places there are nature reserves such as: Eryngium sp. in Mechelinki, Widowo with diversified coastal dune relief, the natural pine forest near Mrzeżyno and the coastal habitats on Sarbsko Lake Sandbar.

\section{Types of dune coasts in Poland}

Polish dune coasts are mainly developed on sandy barriers - linear, depositional, marine originating land forms, that are separated from the mainland by lagoons (lakes) and marshes, and where marine and aeolian accumulation prevail (Fig. 8). Dunes have also developed on the soft moraine cliff coast: typical foredunes developed at the front of moraine cliff coast or aeolian sands on the top of it. Polish dune coasts localized on sandbars (and sandspits) are built by:

- typical foredunes in different stages of development: stabilised and developed from erosive to accumulative phases, in some places with a wide zone of embryo dunes on the upper beach,

- low coast sandy coast plains, recently without foredunes,

- eroded inland dunes (former shifting) of different

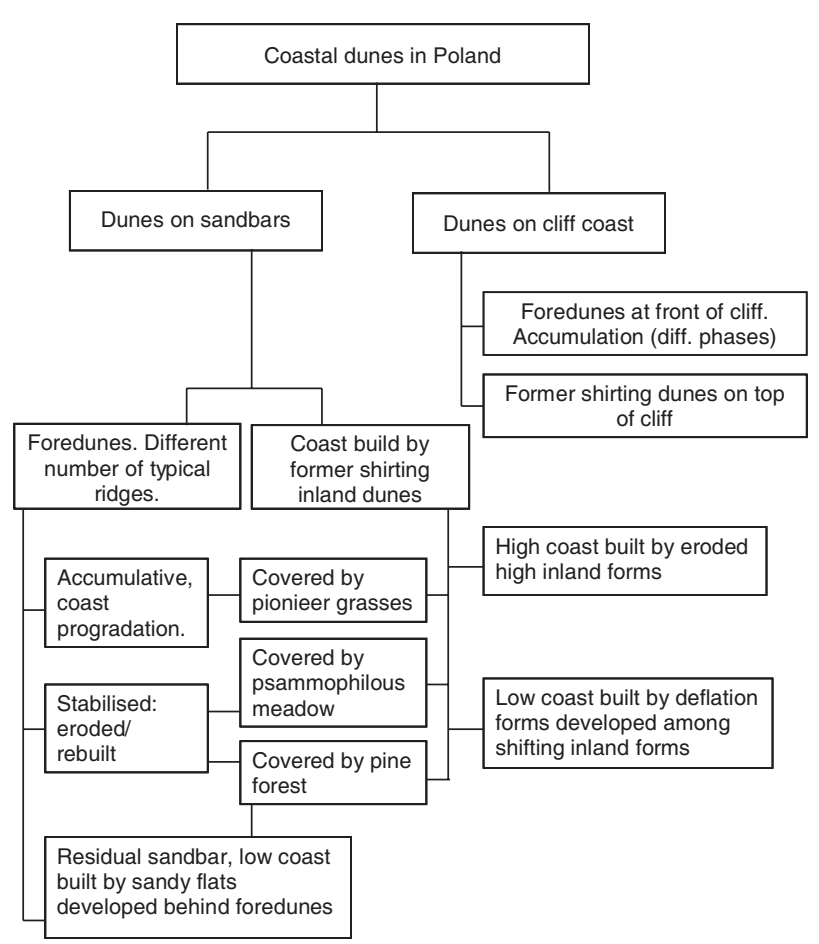

Fig. 8. Classification o coastal dunes type related to origin, dynamic and different plants stages cover (defining phase of its development)

height, from high recently wandering forms to low depressions developed among them; sometimes both types with embryo dunes on the upper beach.

The presented classification describes relation among them due to their dynamics, origin and observed relief (Fig. 9).

\section{Characteristic of sandbars}

The dune belt sections of the Polish coast occur in the form of sandy barriers that separate low-lying and often marshy postglacial valleys like: the Rega and Parsęta rivers and the coastal lakes like: Jamno, Bukowo, Wicko or Łebsko. On the Polish coast most of them are so called welded barriers connected by land from both sides and covered by varying dune forms (Fig. 10). Each barrier may be divided by rivers, streams or channels connecting lakes with the sea. There is also one typical large sandspit - Hel Peninsula and other similar small forms (without dunes). The geological structure of a sand barrier core contains sea and beach sands covered with sandy aeolian deposits. They are also composed by fluvioglacial or limnic sands with marine and organic deposits in the bottom and back of the barriers. They range in size.

On the Polish coast two basic types of sandy barriers can be distinguished: narrow and wide ones. The width of the sandbars range from $50 \mathrm{~m}$ to $3000 \mathrm{~m}$. The longest Polish sandbars are the Świna Gate Sandbar, Łeba Sandbar, Vistula Sandbar, and the Hel Peninsula Spit. Except for the Hel Spit, these are also the widest sandbars with complex aeolian reliefs. The narrowest sandbars, 

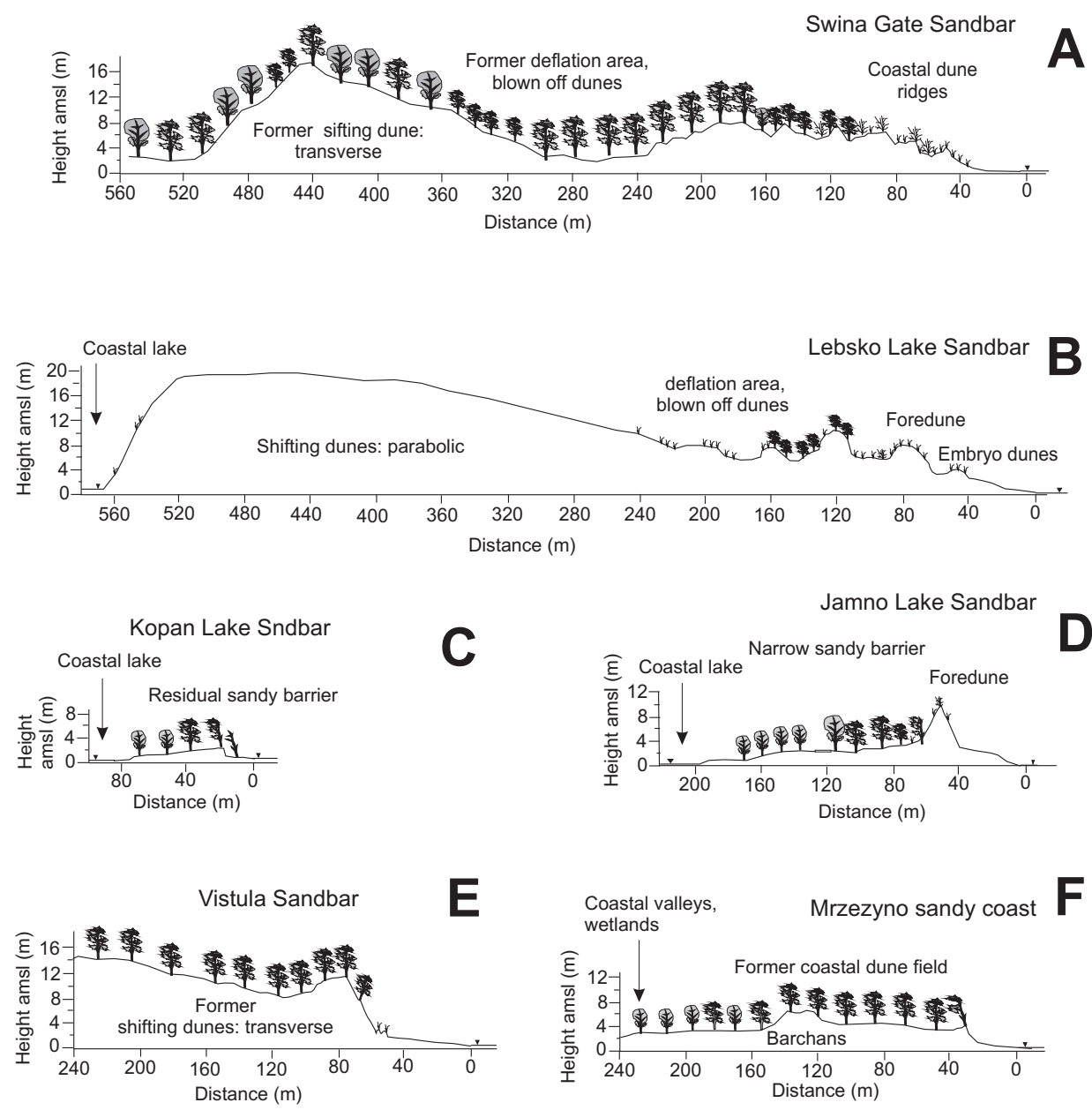

Fig. 9. Typical examples of dune coast relief related to origin and dynamics

A - wide barrier, progradating coast with numerous coastal dune ridges and former wandering ridges, B - wide barrier, slowly progradating coast with foredune and shifting dunes supplied by sand blown off from the beach, $\mathrm{C}$ - very narrow, residual barrier without coastal dune ridges, $\mathrm{D}$ - narrow sandbar with one foredune, $\mathrm{E}$ - coast built by formerly shifting, inland dunes (occasionally with ephemeral embryo dune), $\mathrm{F}$ - coast build by lowering among formerly shifting inland dunes

with one ridge of foredune, are the sandbars of Bukowo Lake: 90-250 m, Jamno Lake: 200-700 m, sandbar banks of the mouths of Parsęta and Wieprza Rivers and Karwia swamps. The narrow barriers have a single foredune ridge in the erosion phase and narrow beaches up to $25 \mathrm{~m}$ wide like the spits of the Dziwna channel (Bohdziewicz 1963, Rosa 1963, 1984, Racinowski 1995, Racinowski, Seul 1996, Racinowski, Seul 1998), the Jamno and Bukowo lakes barrier (Zawadzka-Kahlau 1995, 2009, Łabuz $2003 \mathrm{~b}, 2012 \mathrm{c})$. Other strongly eroded ones do not have foredunes and their coast is mainly built up by low lying sand sheets, that have been developed behind their former ridges, such as: the sandbar of Kopań Lake, Karwia lowland, part of Hel Peninsula (Tomczak 1995a, Zawadzka-Kahlau 2009, 2012).

The widest barriers are covered with chains of foredune ridges in different stages of evolvement, marking land progradation, such as the Świna Gate Sandbar (Keilhack 1912, Piotrowski 1999, Osadczuk 2004, Reimann et al. 2010) or the Vistula Sandbar (Tomczak 1995b, Mielczarski 1997, Mojski 2000). The width and number of ridges vary and depend on the previous rate of coast increase and withdrawal. Other relief forms are also related to their own development phases and sand accumulation (Rosa 1963, Bohdziewicz 1963, Rosa, Wypych 1980). In places where the accumulation was quick, the ridges are lower and narrower, and the depressions between them are wider. In the places where growth has been slower and the supply of sand deposits from the beach took longer, ridges are higher and wider as well as closer to one another (or even in some cases connected, creating a wide coastal ridge). In front of these ridges are wide beaches of up to $100 \mathrm{~m}$.

On the eastern coastline we can distinguish spit types of barriers (Rucińska-Zjadacz et al. 2009): the longest is Hel Peninsula - with recurved spit ends (promontory) and still developing smaller forms as with the Szpyrk promontory - small type of cuspate foreland and Ryf Mew - elongated and mainly submerged sandy bar between the Puck Lagoon and the Gulf of Gdańsk (Musielak 1980, Tomczak 1995).

Below is a short relief description of selected sand bodies that are currently building up along the Polish coast:

- the Vistula Sandbar (over $70 \mathrm{~km}$ long and encompassing parts of Poland and Russia): the longest on 

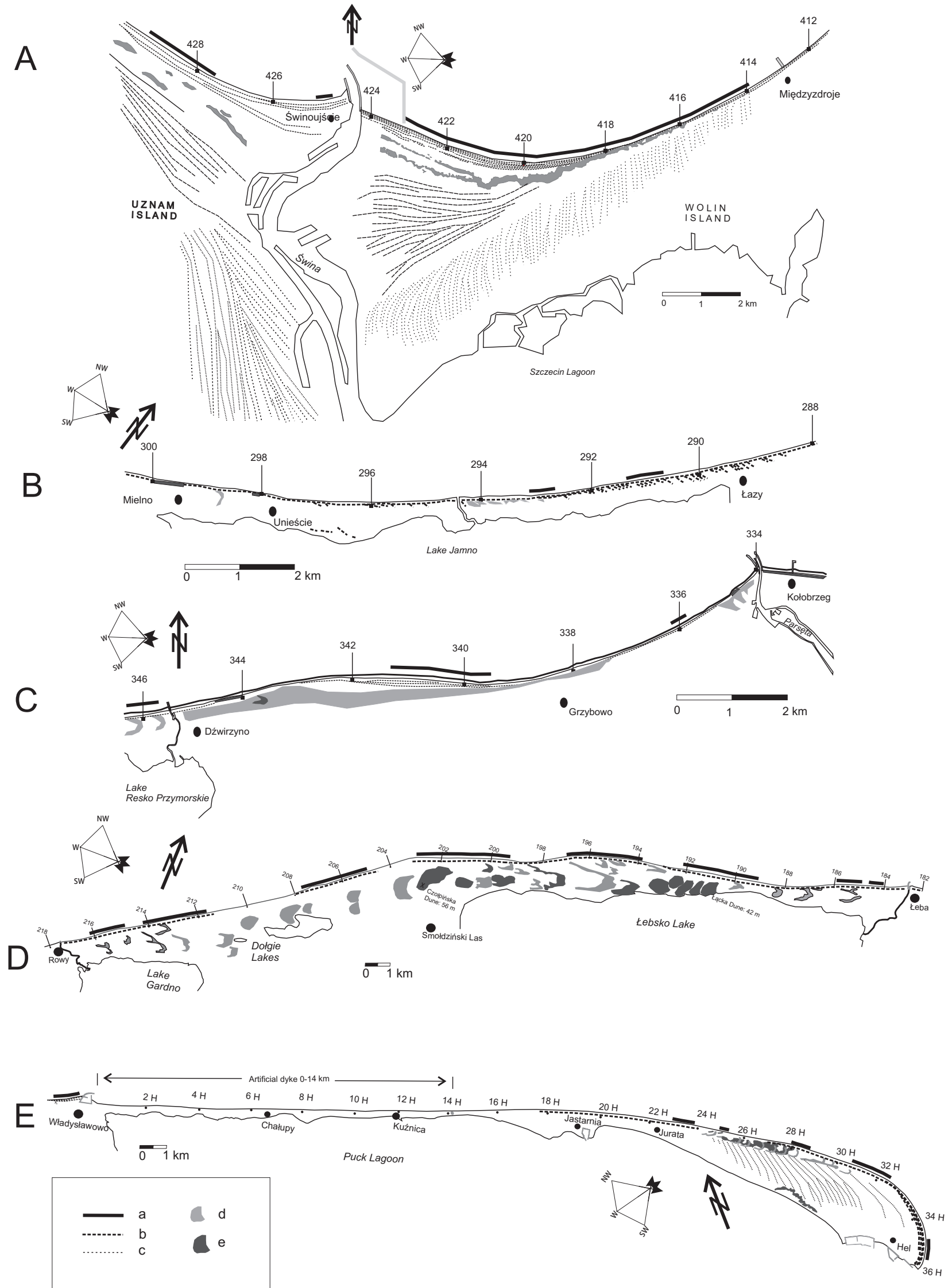

Fig. 10. Examples of Polish sandbars

A - Swina Gate Sandbar, high progradation, numerous dune ridges, transverse dune, B - Jamno Lake Sandbar, narrow, erosive with one coastal ridge, C - Lake Resko - Parsęta River dune belt with transverse ridge and diverse coast built, D - Gardno-Lebsko Lakes Sandbar, wide covered by formerly and recently shifting dunes and diverse dune coast, E - Hel Spit, narrow barrier with wide promontory covered by foredunes and transverse dunes; a) foredune development, b) foredunes, c) older coastal ridges, d) fixed inland dunes, e) shifting inland dunes; coast kilometrage marked on maps 
the Baltic coast, separating the Żuławy land depression by the Vistula River delta and the Vistula Lagoon from the Gulf of Gdańsk (Rosa 1963, Mojski 1995), the oldest longitudinal ridges - so called brown dunes are separated from the sea by high transverse ridges and young foredunes (Bohdziewicz 1963, Tomczak 1995b, Mojski 1995, Mielczarski 1997, Fedorowicz et al. 2009), along the barrier there is also a belt of transverse dunes with heights of 20 to up to $47 \mathrm{~m}$ (Camel Hummock near Krynica Morska). Recently the coast has eroded and accumulated alternately (Musielak 1980, Kobelyanskaya et al. 2011, Łabuz 2007b) and progradation can be seen in the vicinity of the mouth of the Vistula and its artificial channel - Sobieszewska Island (Labuz 2012b),

- the Hel Spit (36 km long): $2 / 3$ rds of it is erosive with many washover fans, artificial nourishement and at the wider end covered by stabilised foredunes that show phases of promontory development (Pazdro 1948, Furmańczyk 1995, Tomczak 1995b, 1999 Wróblewski 2001), also with newly developing foredune ridge (slowly due to exposition not favouring for strong wind action). This part is covered by high wandering dunes up to $25 \mathrm{~m}$ high (starting from SE of Jurata village), shifted over to older foredunes, some of them still unstable (Łabuz 2005a) due to material deficit. The Hel Spit promontory has also recently eroded (Rucińska-Zjadacz et al. 2009),

- the Szpyrk promontory (1 km long): a narrow, up to 2-3 m wide, semi-cuspate foreland, shaped by a two sided transport along the coast but with low hydrodynamic energy (Musielak 1980, Rucińska-Zjadacz et al. 2009), devoid of aeolian forms, except for a few ripples on the beach,

- the Karwia Sandbar (12 km long): narrow, erosive and with one dune ridge (Tomczak 1995a, Zawadzka-Kahlau 1999, 2009) with a partly artificially formed ridge and with the remnants of shifting parabolic dunes near Dębki - Karwieńskie Błota villages (typical example is in Widowo Reserve), swamps and marshes are typically seen behind the narrow dune belt,

- tke Łebsko-Gardno Lakes Sandbar (40 km long): a complex of lakes and lowlands separated by a dune belt, famous for its shifting barchans type and parabolic dunes, with a rate of $4 \mathrm{~m} / \mathrm{y}$ (Miszalski 1973, Borówka 1980, 2001) and a height of up to $42 \mathrm{~m}$ of shifting forms (Łącka mount) and $56 \mathrm{~m}$ of stabilised forms (Czołpińska mount), also with typical foredunes and erosive coastal parts built by these wandering forms (Łabuz 2005a), different stages of dune remobilisation has been observed (Rosa 1963, Marsz 1966, Tobolski 1972, 1980, Borówka 2001) lately with dynamics aeolian processes on the beach, foredunes and shifting forms (Borówka M. 1979a, 1979b, Borówka 1980, Rotnicki, Borówka 1999, Hildebrand-Radke 1999, Rotnicka 2011a, 2011b),

- the Jamno Lake Sandbar (10 km long): a typical barrier separating the lake from the sea with one mainly erosive ridge (Bohdziewicz 1963, Zawadzka-Kahlau 1995, Łabuz 2003b, 2012c), erosion has accelerated due to coast's exposure to storm surges and strong winds. This is also causing strong deflation and foredune ridge retreat in landward direction, exceeding up to $2 \mathrm{~m} / \mathrm{y}$ ( Labuz 2012c),

- the Dziwna River Sandbar (10 km long): built by two spits with a narrow dune belt, partially on Wolin Island with higher foredunes, parts connected to the mainland are mainly eroded (in Dziwnów town), where there is also an artificial dune (Bohdziewicz 1963, Rosa 1963, Racinowski 1995, Racinowski, Seul 1996, 1998, Musielak et al. 2005, Furmańczyk et al. 2012), erosional processes still prevails there,

- the Świna Gate Sandbar (16 km long in Poland and $4 \mathrm{~km}$ in Germany): is a barrier made up of two spits developing appositionally from eroded cliffs on the Uznam and Wolin islands, that appositionally Szczecin Lagoon from the sea (Keilhack 1912, Piotrowski 1999). Its origin: geological structure, sand granulation, morphodynamics, vegetation diversification and relief have been studied by many authors (Keilhack 1912, Prusinkiewicz, Noryśkiewicz 1966, Bohdziewicz 1963, Rosa 1963, Musielak 1991, Racinowski, Seul 1996, Piotrowski 1999, Osadczuk 2004, Reimann et al. 2010), the oldest foredunes - brown ones that are partially eroded on the eastern part of barrier or covered over by younger yellow or transverse ridges, up to $22 \mathrm{~m}$ high, in the middle sections; accumulation still prevails in the middle and western part of the Karsibór spit (Keilhack 1912, Musielak 1995, Baraniecki, Racinowski 1996) and is the highest on Polish coast (Łabuz 2003d, 2005b, 2009a).

The largest and longest dune belt is localised in the middle-eastern part of the coast: between Rowy and Karwia. There, almost $75 \mathrm{~km}$ of the coast is covered by foredunes, older coastal ridges, stabilised former shifting dunes or wandering coastal forms built by high sand structures as well as low depressions and long sections of foredunes, which together separate the lakes and marshes of the coastal lowland from the coast.

\section{Coast built by foredunes}

Typically the sandbar coast is covered by a single ridge (Bohdziewicz 1963, Zawadzka-Kahlau 2012) with a cut off - cliffed seaward slope, occurres in the intensely eroded sections of the coast (e.g. sandbars of the lakes in the middle Polish coast). In the eroded sections of the sandbars, receding dunes enter the land deposits. In such situations, marshy inland deposits (e.g. peat or lake gyties) emerge on the beach under the present aeolian deposits (Bohdziewicz 1963, Rosa 1963, 1984, Rosa, Wypych 1980). At present, this phenomenon can be seen in the areas of Kołobrzeg, Mrzeżyno, Dźwirzyno, Łazy, Rowy and the Gardno Lake Sandbar. Due to erosion, some sandbar coasts are completely without a foredune or have this form only in a vestigial shape (e.g. the Sandbar of 
the Kopań Lake) less than $50 \mathrm{~m}$ wide (260-268 km¹), the Karwia Lowland Sandbar with an artificial ridge and with a low sandy area (237-244 km) or sandy coast Eastward of Kołobrzeg town, where dunes separating land swamps have been abraded (327-329 km).

Less frequently seen sandbar coasts are covered by several dune ridges situated parallel to one another and with evidence of subsequent stages of sandbar growth from the past (Świna Gate Sandbar, Wicko, Łebsko Lakes and Vistula Sandbar or the Hel promontory Spit). In these areas the seaward slope of the first dune, the foredune, is usually gently curved and shows accumulation tendencies. The accumulation and progradation of these coasts are best represented by the generation of dunes in the Świna Gate Sandbar (Keilhack 1912, Rosa 1963, Prusinkiewicz, Noryśkiewicz 1966, Osadczuk 2004, Łabuz $2005 \mathrm{~b}$ ), with three generations of foredune ridges. The accumulative coast of this sandbar is mainly built up by foredunes with a height from 5 to $12 \mathrm{~m}$ and in the background by older foredunes separated by flat, slightly rolling areas with a height of 2-2.5 $\mathrm{m}$ a.m.s.l. (Bohdziewicz 1963, Labuz 2005a). On coast with such fast accumulation, upper beach may be covered by one or two chains of small hillocks - embryo dunes with height of 1 to $2 \mathrm{~m}$ (the largest one in area: 48-49 km on Vistula Sandbar, $30 \mathrm{~km}$ on the Hel Peninsula, $142 \mathrm{~km}$ and $146 \mathrm{~km}$ on the Karwia Sandbar, 190-191 km, 202-203 km, 205-207 km and $211-212 \mathrm{~km}$ on the Łebsko-Gardno Lakes Sandbar, 143-144 km, 148 km on the Wicko Lake Sandbar 293 km on the Lake Jamno Sandbar, 419-422 km on the Świna Gate Sandbar).

Due to local dynamics and coast undulations, partial sandbars show indications of accumulation. Accumulated sections alternate with eroded ones. This phenomenon is visible mainly on long sandy sections between Rowy and Karwia on mid-eastern part of the coast. There, the aligned coast resembles a stepped one: from locations with accumulation to small bays with erosion directed to North-East.

\section{Coast built by formerly shirting inland dunes}

Behind the coastal forms, the land relief of the barriers is covered by dune fields - secondary dune sheets: shaped by complex formerly shifting sand that created parabolic, barchans or transverse dunes with low lying sand flats (Świna Gate Sandbar, Wicko Lake Sandbar, Łebsko-Gardno Sandbar, Stilo-Białogóra-Dębki sand dune belt) so-called coastal dune fields (Rosa 1984). These forms are separated by usually flat or slightly rolling areas, with a height ranging from 2 to $5 \mathrm{~m}$ above mean sea

\footnotetext{
Kilometrage classification of Polish coast (500 km long) used by Maritime Institutes has $428 \mathrm{~km}$ of open coast, from $0 \mathrm{~km}$ on the border with Russia on the Vistula Sandspit to $428 \mathrm{~km}$ on the border with Germany on the Świna Gate Sandbar. Hel Peninsula has a separate classification, counted from its start in Władysławowo: $0 \mathrm{~km} \mathrm{H}$ to 36 $\mathrm{km} \mathrm{H}$ on the promontory end and the next 36 kilometers from the side of the Gulf of Gdańsk and Puck Lagoon.
}

level (Fig. 11). The width of the coastal plains covered with dune forms and deposits may reach $3 \mathrm{~km}$. The maximum height of these forms reach $22 \mathrm{~m}$ on the Świna Gate Sandbar, $35 \mathrm{~m}$ on the Wicko Lake Sandbar, $56 \mathrm{~m}$ on the Łebsko Lake Sandbar and $49 \mathrm{~m}$ on the Vistula Sandbar. Due to the deforestation of the coastal areas in the $17^{\text {th }}$ and $18^{\text {th }}$ centuries the latest movement of these forms started (Hartnack 1926).

Prominant inland shifting dunes are from the Łebsko Lake Sandbar. There, in Słowiński National Park is a system of still migrating barchans and parabolic dunes, shifting in an eastward direction due to the influence of dominating winds from the westerly direction (Rosa 1963, Marsz 1966, Miszalski 1973, Borówka 1980, 2001, Łabuz 2005a). The shifting dunes of the Łebsko Lake Sandbar move eastward at an average speed of 1 to 10 m/y (Miszalski 1973, Borówka 1980, 2001). The highest migrating dune is $42 \mathrm{~m}$ high, named Łącka Mount. The most frequent forms there are barchans with relative heights up to $32 \mathrm{~m}$ (Miszalski 1973).

Due to progressive erosion, these forms may be now situated in the direct vicinity of the sea coast and are usually built up similar to a cliff dune coast. The line of the dune edge (land) along such coasts are wavy and correspond to the former older landform features as barchans and low depressed edges; from $2 \mathrm{~m}$ up to $15 \mathrm{~m}$ high. Often the geological structure and the relief of these dune coasts has a distinct lateral profile of barchans and parabolic dunes, as well as their corresponding structures of aeolian sands (Borówka M. 1979a).

The height of this type of coastal dune is not constant and depends on the height of the forms and depressions that divide them. The highest walls of the dune cliffs that have been eroded by the sea in this area are 15-25 m (234-235 km eastward of Ustka town; $210 \mathrm{~km}$ on Gardno Lake Sandspit; $198 \mathrm{~km}$ and $185 \mathrm{~km}$ on Lebsko Lake Sandspit; 178 km, 165 km, 151-152 km and 144 km on Białogóra-Lubiatowo-Dębki and Karwia Lowland Sandbars; $18-20 \mathrm{~km}$ and $27-30 \mathrm{~km}$ on Vistula Sandbar). In some locations, there are rather low coasts formed by inland aeolian deposits, 2-5 $\mathrm{m}$ high, that have formed within the interdune depressions that separate individual, higher depositional forms (352 km near Mrzeżyno, 343-344 km near Dźwirzyno, $143 \mathrm{~km}$ on Karwia Sandbar, 24-25 km on Hel Peninsula). In these locations, inland washover fans are developing. The zone of the direct background of the coastal sandbars may be situated only $1 \mathrm{~m}$ a.m.s.l. There are also places where the inland background of the dunes does not occur at all due to the presence of a coastal lake (the Bukowo Lake Sandbar, Kopań or the marshy areas of the Karwieńskie Swamps or the swamps eastward of Kołobrzeg town).

In the present accumulated sections, these areas can be separated from the sea by a new developing foredune ridge (e.g. Gardno Lake Sandbar - $212 \mathrm{~km}$, the coast in the area of Ustka on the Western side of the Wieprza River mouth $-237 \mathrm{~km}$, the Eastern part of the Świna Gate Sandbar -415 to $416 \mathrm{~km})$. 
Vistula Sandbar (10-11 km)

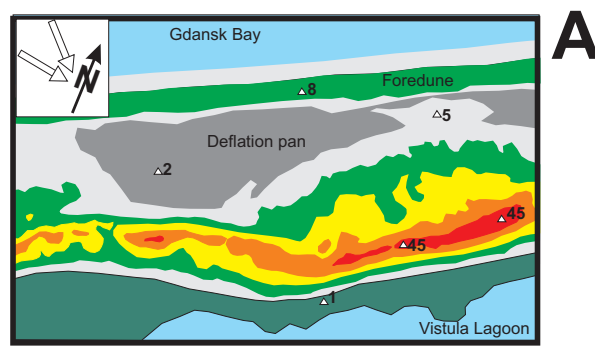

Sarbsko Lake Sandbar/ Stilo $(168-169 \mathrm{~km})$

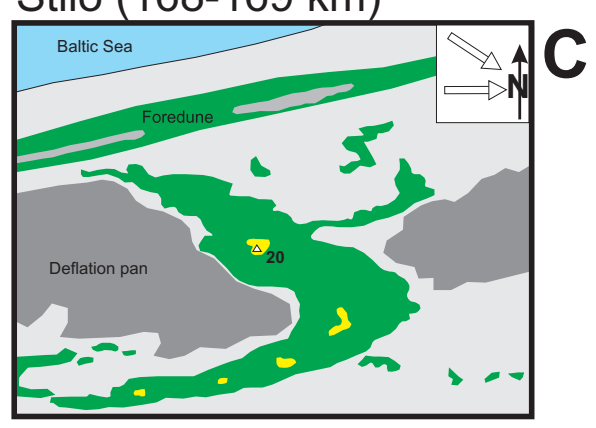

Hel Penisnula Sandspit (29-30 km H)
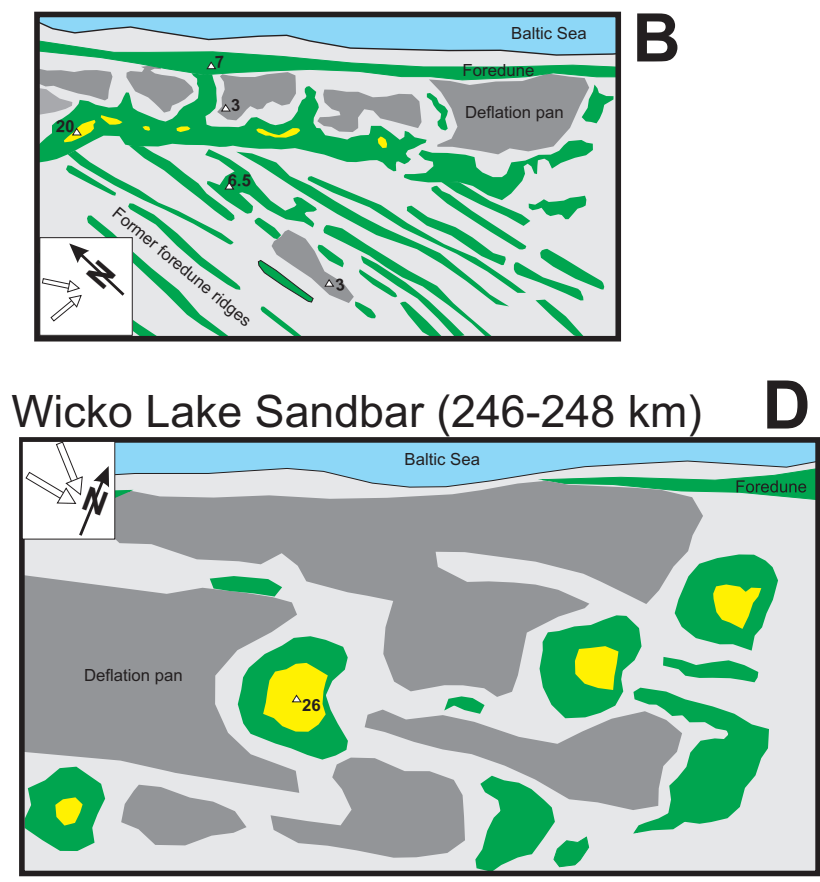

Legend:

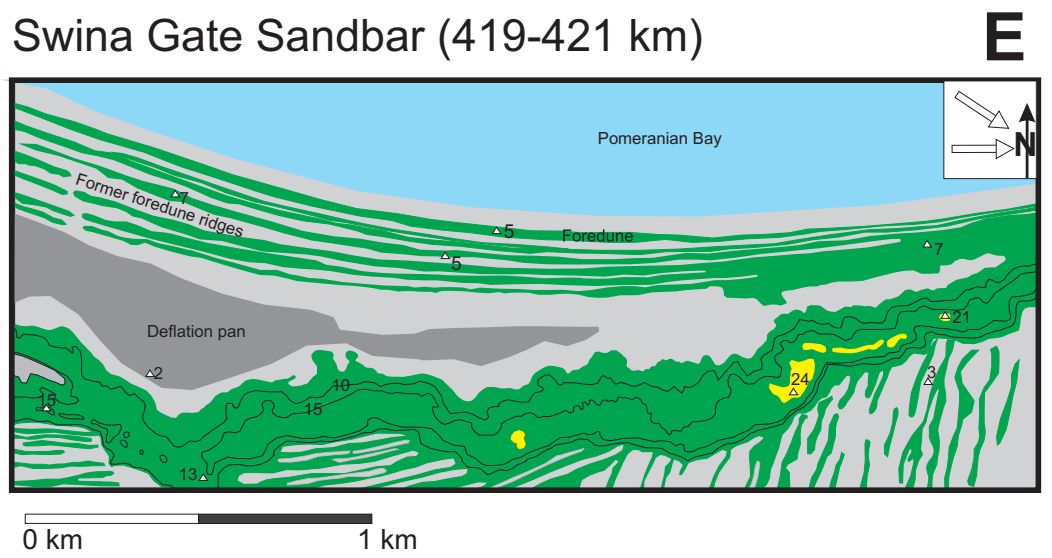

Heights amsl (m)

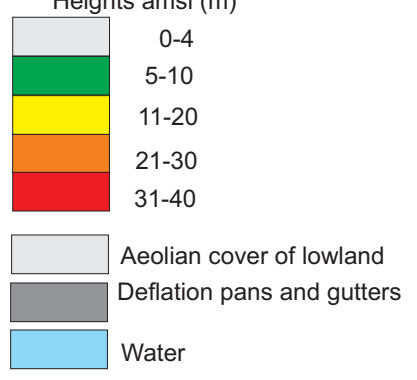

Direction of strong and frequent wind (NW and W)

Fig. 11. The examples of sandy barrier relief

A - barrier with long transverse dune ridge pulled over low lagoon bank with foredune on the coast, Vistula Sandbar, B - wider promontory covered by former foredunes defining land progradation and semi-transverse ridge pulled over, Hel Sandspit, C - wide sandbar covered with former shifting parabolic dunes, Lake Sarbsko-Stilo-Dębki sandbar, D - sandbar covered by former shifting barchans, Lake Wicko Sandbar, E - wide sandbar with few blown off foredunes now building transverse ridge pulled over older foredunes and numerous newer dune ridges defining land progradation, Swina Gate Sandbar (based on topographical maps)

\section{Dune formations on moraine coasts}

In front of a moraine cliff, foredunes occur in their early development stage, where the coast shows accumulative tendencies. The early forms of foredunes are created every $2-3$ years on the Western coast at the foot of a cliff in Wolin, in the area of Wisetka-Grodno (404 $\mathrm{km}$ ), where they can reach 2-4 $\mathrm{m}$ in height. Furthermore, for the last 15 years, they have developed in a moraine section of the coast in the areas of Pustkowo-Pobierowo (375-377 km), where they can reach 2-6 m high. A narrow dune belt is also developing in Władysławowo town (135-136 km), where an accumulation has been prevalent since 1936; after which harbor breakwaters were built. Rather low foredunes (artificially altered) can be found in the Gdansk Bay (Sopot, Gdańsk towns).

Dune coasts also include sections where aeolian sands from coastal plains and sandbars have entered post-glacial moraine deposits (Bohdziewicz 1963, Rosa 1963, Musielak 1995) and presently due to the recession of the coast they form moraine cliffs with a dune on the areas along their tops (east of Ustka and Kołobrzeg towns). However, this is not a typical dune coast example. In the geological structure of this coast are moraine formations: clay deposits, often separated or covered by glacifluvial sands and organic deposits left by sea flows and water bodies that were covered with aeolian deposits. These coasts are usually abraded and commonly as- 
signed to cliff coasts. The height of such coasts depends on the original height of the moraine and ranges from 3-6 m near Kołobrzeg to 15-20 m near Ustka. The thin aeolian deposits are re-formed on the high sandy cliffs built by glacifluvial sands from deposits transported by winds from the cliff's wall that have accumulated at its top (e.g. the cliffs on Wolin Island).

\section{Present dynamics of the main relief forms on the dune coast}

The predominant forms of dune coasts are on coastal beaches with accumulative incipient or initial aeolian forms, established or developing foredunes with inter-dune depressions and washover fans developed on the lower coast or between low dune ridges.

\section{Beaches}

The beaches on the sandy sections of the coast have very different widths and inclinations, which are determined by the dynamics of a given section of the coast (Musielak 1991, 1995). The wind waves are the main factors that shape the beaches. Also sea level changes are important factors that transfer a zone of hydrodynamics from the lower to upper beach (Musielak 1989).

The mean width of beaches in Poland is about 35 $\mathrm{m}$ (Zawadka-Kahlau 1999). The widest are the beaches found in accumulative sections of the coast with $80 \mathrm{~m}$ to $130 \mathrm{~m}$ in the Świna Gate Sandbar and $100 \mathrm{~m}$ in the Lebsko Lake Sandbar, in the Hel Peninsula promontory, the mouth of Vistula River, and the coast near Sopot. The narrowest beaches occur on sections of narrow sandbars that have been abraded by the sea.

The beaches reach a mean height of $2 \mathrm{~m}$ a.m.s.l. On the accumulative sections, beaches covered by aeolian sand reach 2.5-3 m a.m.s.l. In the upper part, next to the dune they are sometimes covered by aeolian form shadow dunes or embryo dunes $0.2-1 \mathrm{~m}$ in height. Their width may range in short time ca. $50 \mathrm{~m}$ (Fig. 12). Aeolian processes' on the beach, rich in sand, occasionally form sandy mezobarchans sheets that cover the beach (Mielczarski, Onoszko 1968, Łabuz 2008). On the more abrasive sections of the coast, beaches are low, 1-1.5 m high, which leads to more frequent erosion of the dunes and recession of the coast.

\section{Embryo dunes}

Embryo dunes are separated by aeolian hillocks on the upper beach and are covered by pioneer grasses (Hesp 1981, 1984). They develop from small shadow dune hillocks during permanent accumulation and sand fixation by plants. Embryo dunes can develop into new ridges after 3-4 years of consistent growth (Hesp 1981, 1984, Carter 1990, Carter, Wilson 1990). This is caused by aeolian accumulation, where the beach is characterized with a positive balance of material and where these forms are stable and protected by high beaches against storm surges. Over the last 20 years, the upper beach of the Świna Gate Sandbar has twice transformed into a new ridge of foredunes, and in certain parts of the sandbar every 4 years a new ridge appears (Labuz 2003d, 2005b, 2009a). After storm surge erosion, washed out forms develop again due

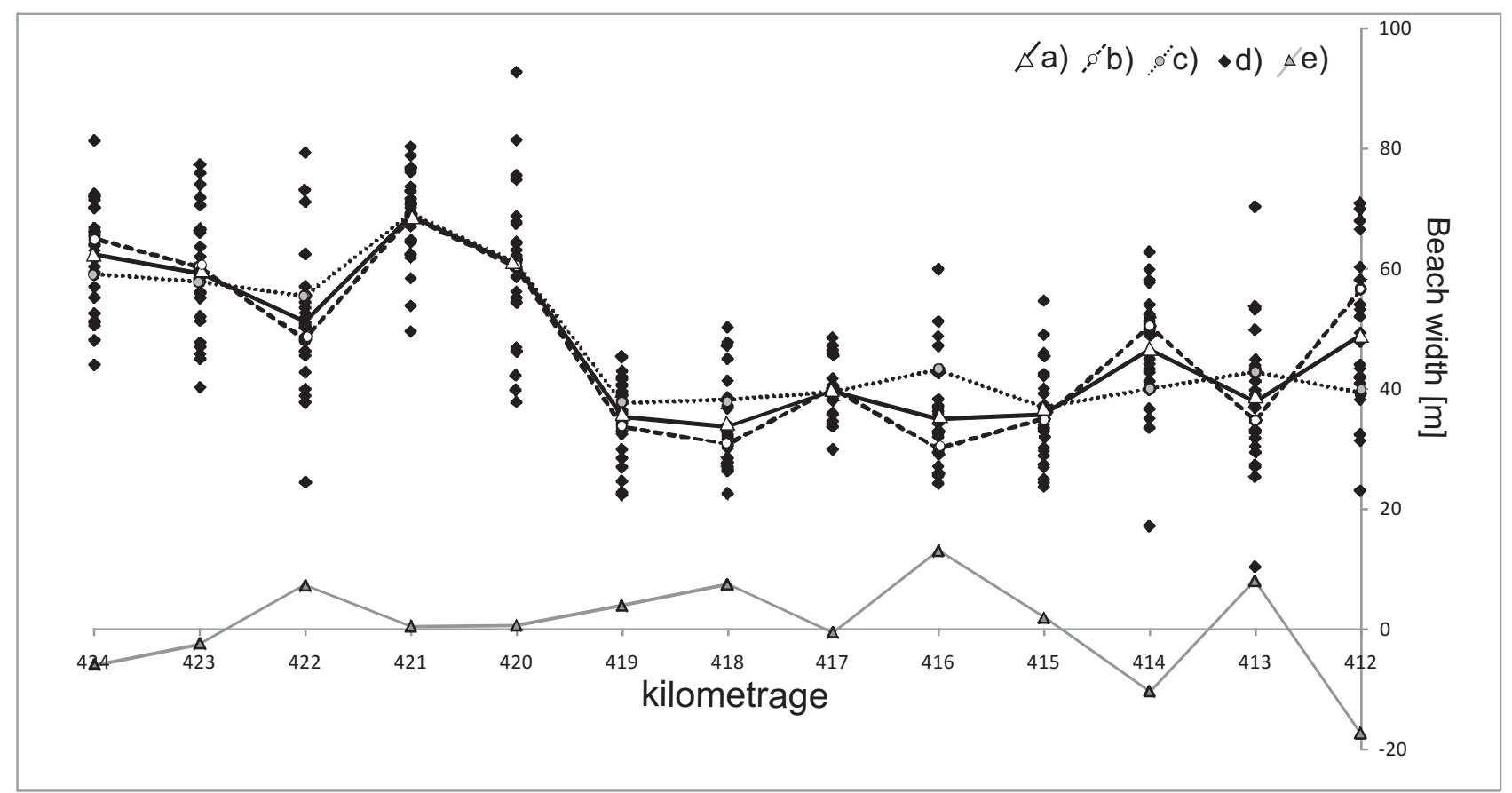

Fig. 12. Swina Gate Sandbar beach width changes

a) mean width 2001-2010, b) mean width 2001-2005, c) mean width 2006-2011, d) periodical width, e) differences in width between 01/05 and 06/11 (Labuz 2012a) 
to plant growth in the spring. They reach heights of up to $3 \mathrm{~m}$ above the surface of the beach. They can be found in several locations, mainly along the widest barriers of the Polish coast (f.e. 212 km, 202 km, 191 km, 18 km, 30 km $\mathrm{H})$. They can develop only on beaches up to $3 \mathrm{~m}$ in height due to annual winter erosion. Any typical storm surge reaches upper beach and destroys it, higher beaches can withstand even above-average catastrophic storm surges (Fig. 13). Therefore embryo dunes may still develop.

\section{Foredune ridges}

Foredunes - also called incipient dunes (Hesp 1984) - are an indicator of the accumulative character
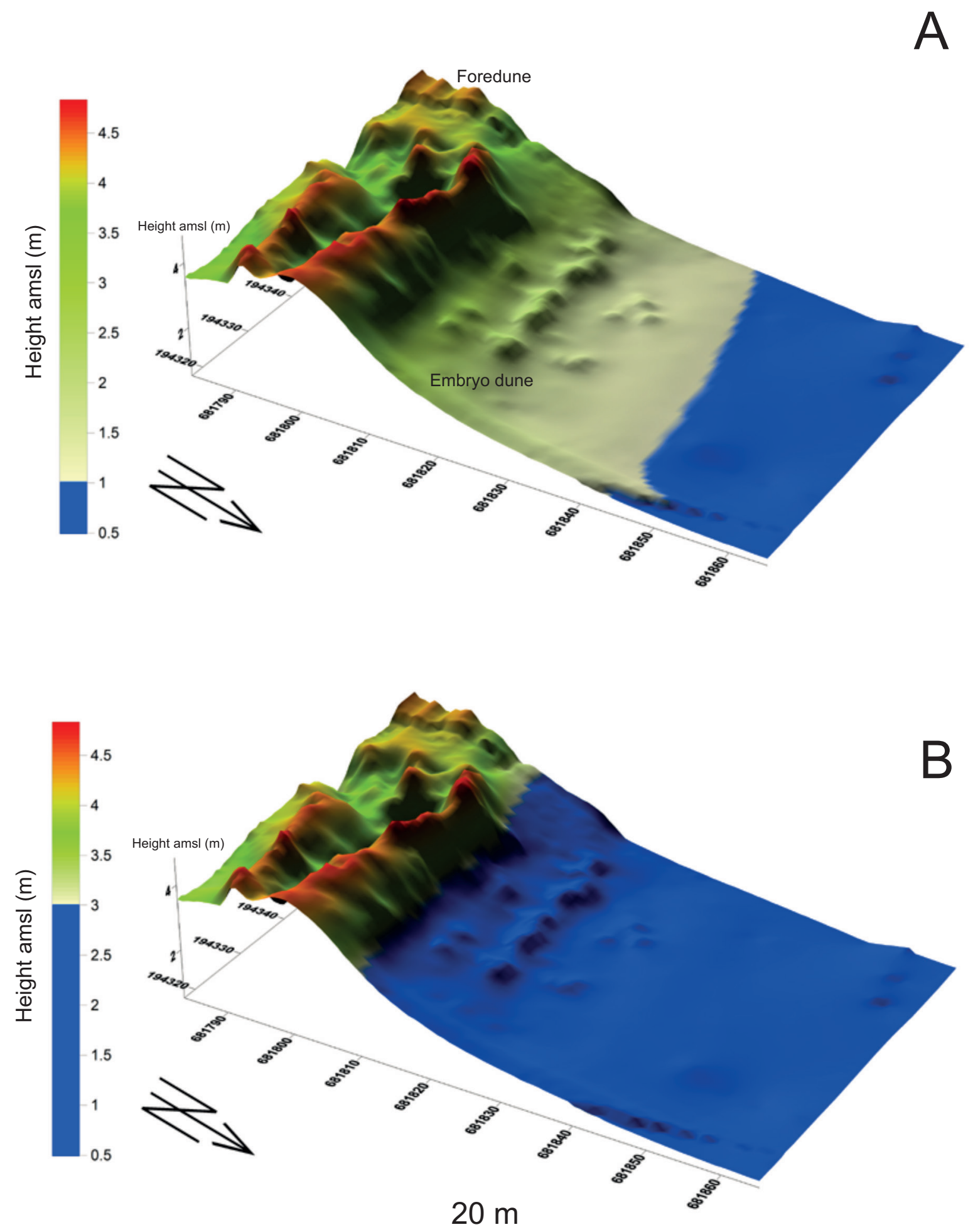

Fig. 13. Scenario of beach and embryo dune over flow by storm surge (Swina Gate Sandabr) A - water level $1 \mathrm{~m}$ above amsl, typical annual situation, B - water level $3 \mathrm{~m}$ amsl, catastrophic surge 
of the coast. The old fixed dunes are covered by plants of older successive stages, the youngest ones are covered by pioneer vegetation. This is a very dynamic form, shaped by aeolian processes and storm surges. A foredune is a very rich habitat of plants and animals. It can protect low and developed areas in a natural manner. At the present time this is one of the most valuable natural environments for the inhabitants and tourists in the coastal areas. Foredune ridges have various widths and heights (Bohdziewicz 1963, Rosa 1963, Łabuz 2005a). They can be up to a few dozen meters wide and 4-8 $\mathrm{m}$ high, less frequently they reach $12 \mathrm{~m}$ a.m.s.l. (Marsz 1966, Miszalski 1973, Borówka M. 1979a, Borówka 2001, Labuz 2005a). Low and narrow ridges, up to 6 $\mathrm{m}$, characteristic of a quickly progradating coast, can be found on the Świna Gate Sandbar, the Lebsko Lake Sandbar, the Hel Peninsula and at the mouth of the Vistula River. Higher dunes, up to $12 \mathrm{~m}$ high, occur between Pogorzelica and Mrzeżyno, west of Kołobrzeg and Mielno, and near Darłówek village. The remaining sections of the coast are mostly covered with ridges that are 8-10 $\mathrm{m}$ high.

On the Polish coast there are a few dynamic types of foredunes (Fig. 14):

- coasts with fast progradation and several small sandy ridges,

- stable coasts with one high grooving form,

- more or less stable coasts with dunes occasionally eroded and slowly restored,

- accumulative coasts but with blown off and withdrawing ridges due to several various erosion phenomena and strong onshore winds, where vegetation is rare.

Foredunes are very dynamic forms in short time and may change into different form, that may stay in the same position for many years, till erosional phase (Fig. 15). The dynamics of sand volume building that form is an indica- tor of long and short-term variability, and should be basic indicator of coastal dunes changes (as was mentioned).

More than $70 \%$ of foredune ridges are older forms entirely anchored by flora and recently eroded by the sea. In only a few locations, the coast consistently builds an active wide dune ridge that slowly grows towards the sea. On the Polish seaside, incipient, developing foredune ridges occur on a majority of sandbars but also mainly on shorter sections of the coast. The currently forming foredunes are only partially covered with pioneer vegetation and occur infrequently. In natural conditions, they can be found on longer sections of the coastline in the areas of the Świna Gate Sandbar, the Łebsko-Gardno Lakes Sandbar, near Grzybowo, the Hel Peninsula and in the vicinity of the Vistula River mouth. The youngest foredunes are also formed in areas affected by breakwaters, near river mouths, which force an accumulation of sand deposits and the progradation of beaches (Świnoujście town, the Eastern side of Dziwnów, Western coastlines such as in Dźwirzyno, Darłówek, Ustka, Łeba, Władysławowo, and the mouth of the Vistula River).

\section{Inter-dune depressions}

Between the forms of aeolian accumulation there are numerous depressions forms: swales, gutters, or niches. Between the ridges of foredunes these forms assume the shape of deflationary gutters that divide subsequent ridges. Often the gutter bottoms are covered by dune hillocks with heights up to $0.5 \mathrm{~m}$ (Labuz 2005a). The width of these interdune gutters depends on the rate of coast accumulation which determines the distance of the formation of the new ridge to the previous one. These forms occur most frequently on the Swina Gate Sandbar, the Łebsko-Gardno Sandbar and the Hel Peninsula promontory. The widest swales are 30-40 m wide - on the Świna Gate

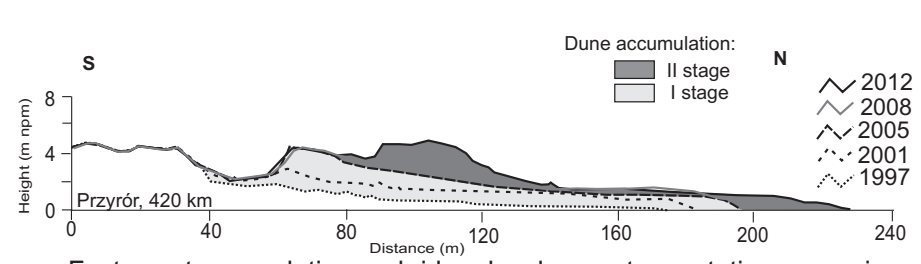

Fast coast progradation and ridge development, vegetation succesion
A

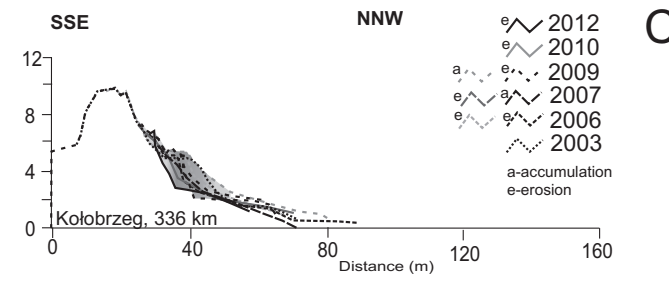

Coast fluctuations, ridge erosion and rebuilt, fluctuations of vegetation

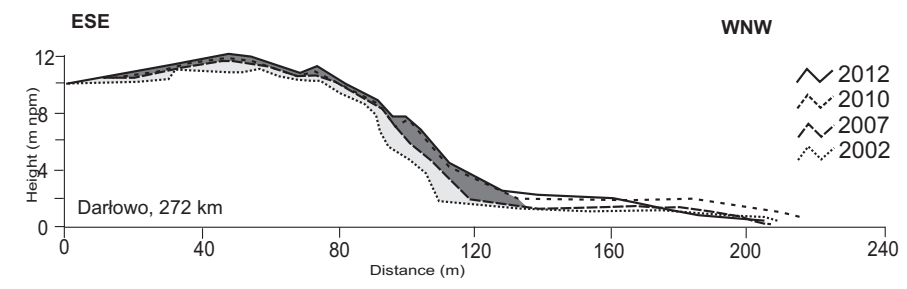

Coast stablisation, slow growth of wide roredune ridge, slow change in vegetation

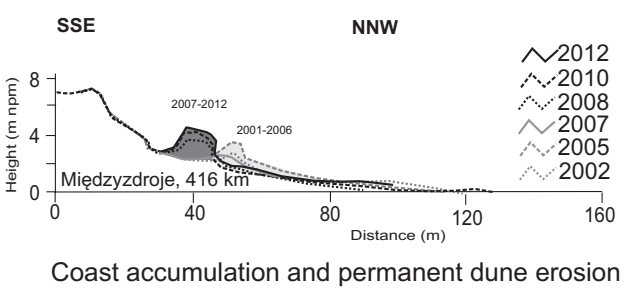

Coast accumulation and permanent dune erosion
lead to foredune withdraw, vegaetation recession

Fig. 14. Classification of foredunes dynamics

A - permanent coast progradation and dunes development, B - stable coast and single dune growth, C - coast and foredune fluctuations, D- Aeolian accumulation alternately with sea erosion leading to foredune withdrawing but still developing 


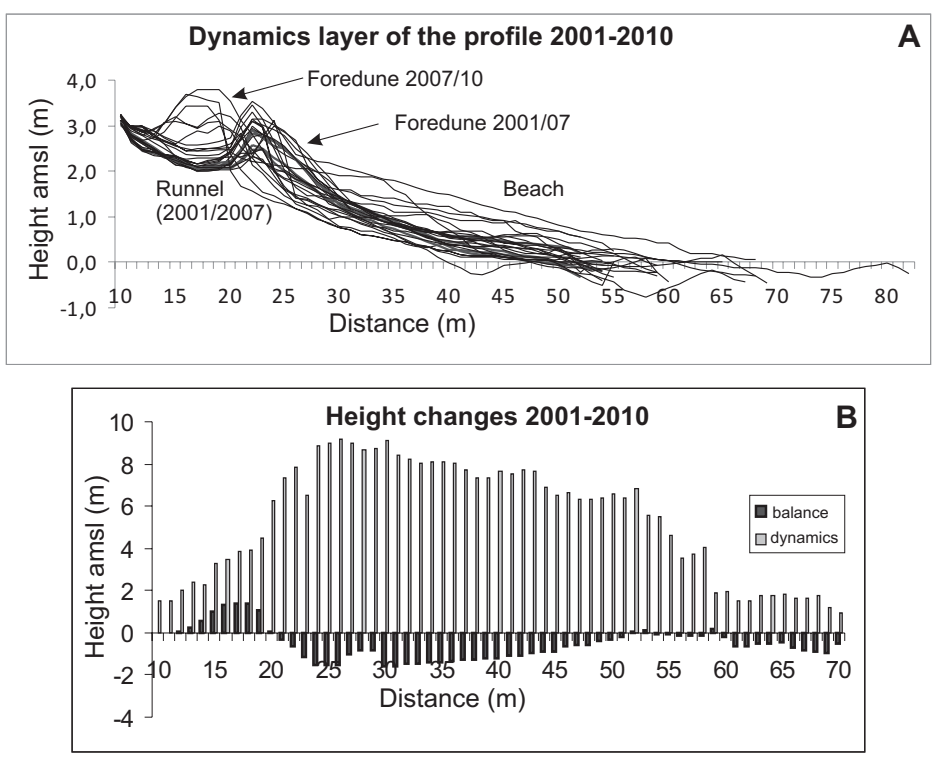

Fig. 15. The foredune dunamics and relief balance

A - profiles relief dynamics, B - height changes and balance

Sandbar and the Lebsko Lake Sandbar. They often do not exceed 2-2.5 $\mathrm{m}$ in height a.m.s.1. During autumnal-winter storm surges, after the breakdown of dune ridges into gutters, washover fans begin to emerge. These forms are frequently composed of organic material - shells, wood and plant detritus mixed with sand.

\section{Washover fans}

Frequently the direct backdrop of low and narrow foredunes contains washover fans caused by water that overflows the ridges during storms (Rudowski 1986, Wróblewski 2001, 2009, Łabuz 2009c). The fans result from the accumulation of sediment transported by the sea onto the upper beach or the runnel beyond the foredune. After heavy storms these forms are frequently found behind foredunes of over $3 \mathrm{~m}$ in height (Fig. 16). The surfaces of washover fans are uneven and inclined towards the land, with small erosive cuts. They reach a length of several meters and a width from one meter to tens of meters. Their outline is irregular, with numerous several meter long ledges. Both the escarpment and the surface of the fan are quickly changed by the wind, causing the obliteration of the original relief. As a result of the relief's rejuvenation, washover fans are subject to secondary aeolian processes, and thus new dune ridges appear: so-called antidunes (Barwis, Hayes 1985, Rudowski 1986). These forms are associated with a different type of vegetation than in a circumjacent environment, with pioneer species entering the new formation. The fans are composed mostly of unlaminated layers with an irregular or more frequently streaked arrangement, with the bottom erosive surfaces acting as a gap in the sedimentation. Fans most frequently occur on the upper beach and at the foot of washed-over foredunes. On the upper beach, fans often occur after average storm surges on all investigated sections of the coast. They mostly occur as organic debris or sediments of organic matter. In spring, the debris contributes to the development of pioneer vegetation habitats. More permanent washover fans can be found on these coastal sections, where the upper beach is sufficiently high above mean sea level (more than 3 a.m.s.l.). Due to the various heights of the coast above sea level and its relief, and due to the heights of storm surges, washover fans are formed by:

- waves washing onto the upper beach,

- overtopping of the foredune,

- cutting of the dune by advancing water.

These forms can be found in the area of Karwia Sandbar, on the Hel Peninsula, the Łebsko Lake Sandbar, the Wicko Lake Sandbar and the Świna Gate Sandbar (Labuz 2009c).

Washover fans have important functions in the dynamics of a dune coast:

- they rejuvenate the relief, causing an increase in the dynamics of the substrate already fixed by vegetation,

- deliver organic matter and cause an increase in vegetation, thus increasing biodiversity.

\section{Deflation forms}

The deflation forms on coastal dunes are formed in areas with low vegetation coverage and exposure to prevailing strong winds blowing from the sea towards the land. In such regions, deflation bowls, larger pans, narrow or wider gutters or troughs are created - erosive forms of aeolian origin. These forms are often associated with deflation on transgressive dunes, where swale systems may have developed. Humans and wind are the main factors causing dune erosion. In the last 10 years the size of deflation forms has grown at an accelerated rate. This was due in part to the interference of mass tourism and system changes from stable to erosive ones. However on the natural parts of the coast erosive forms are increasing the dune diversity. 
S

[m amsl]

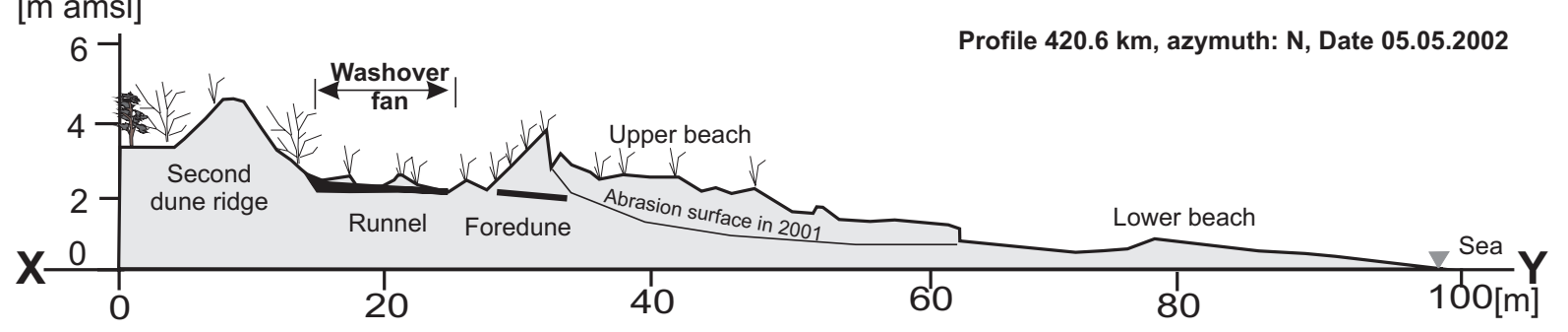

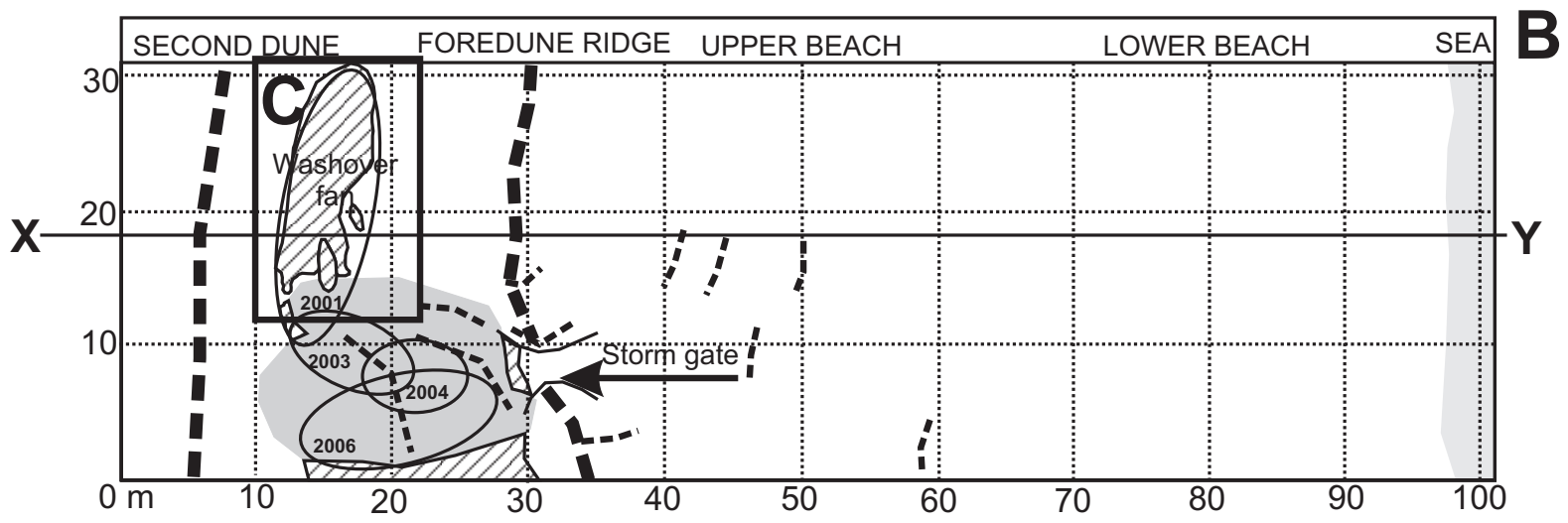

2003 $1 \bigcirc 2: 3 \vartheta_{4}$

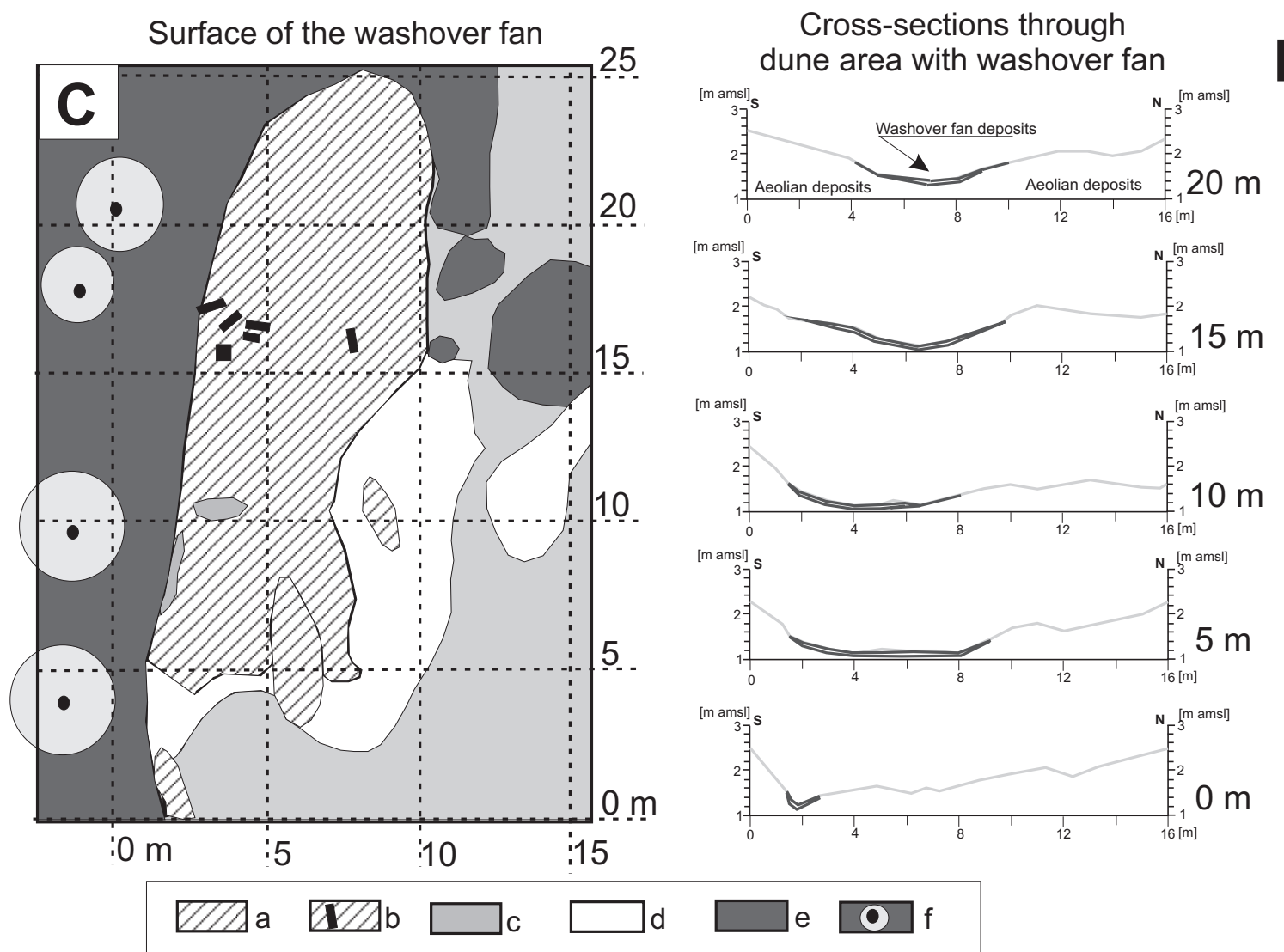

Fig. 16. Formation and localization of storm washover fans on $420.6 \mathrm{~km}$ of the coast

A - cross-section and localization on coast profile, B - map of location in the dune runnel and surface of the strom washover fan: 1 - coverage area and date of storm washover fan, 2 - area of renewed aeolian accumulation, 3 - dune and embryo dune ridges, 4 - deposits of washover fan dated on 11.2001. $\mathrm{C}$ - enlarged area: $\mathrm{a}$ - sediments of the storm washover fan, $\mathrm{b}$ - wood particles $0.5 \mathrm{~m}$ long, $\mathrm{c}$ - present aeolian accumulation, d- surface fixed by algae and grasses, $\mathrm{e}$ - surface fixed by mosses and other plants, $\mathrm{f}$ - willow clumps of fixed dunes, $\mathrm{D}$ - washover fan cross-sections presenting its relief 
Most deflation gutters and pans are located crosswise to the dune ridges and the shore from Northwest to Southeast. Their presence has been found in many parts of the coast, the biggest enlarging areas are near Mrzeżyno, Dźwirzyno, Kołobrzeg, on the Jamno Lake and Bukowo Sandbars, and in the area of Krynica Morska to Piaski coastal resorts on the Vistula Sandbar. These sections of the coast are exposed to the most frequently produced strong winds from the NW sector in autumn and winter. The largest area of deflation forms on secondary dune sheets have developed in Słowiński National Park on the Łebsko-Gardno Lakes Sandbar and the Hel Peninsula Promontory.

A narrow beach with negative material balance that often has strong winds from the sea are not favorable to coastal dunes that have rebuilt after storm surge erosion. The result is a deeper linear deflation, aeolian corrasion and slow dune movement on land. The processes of deflation is increased by the "openwork" structure of plants covering the dunes and the more rare pine forest in coastal areas (or its total scarcity). The decrease in surface roughness results in the blow off of finer material. These forms are an indicator of the diversity dynamics of coastal dune systems and deliver sediment to rebuild the dunes in other
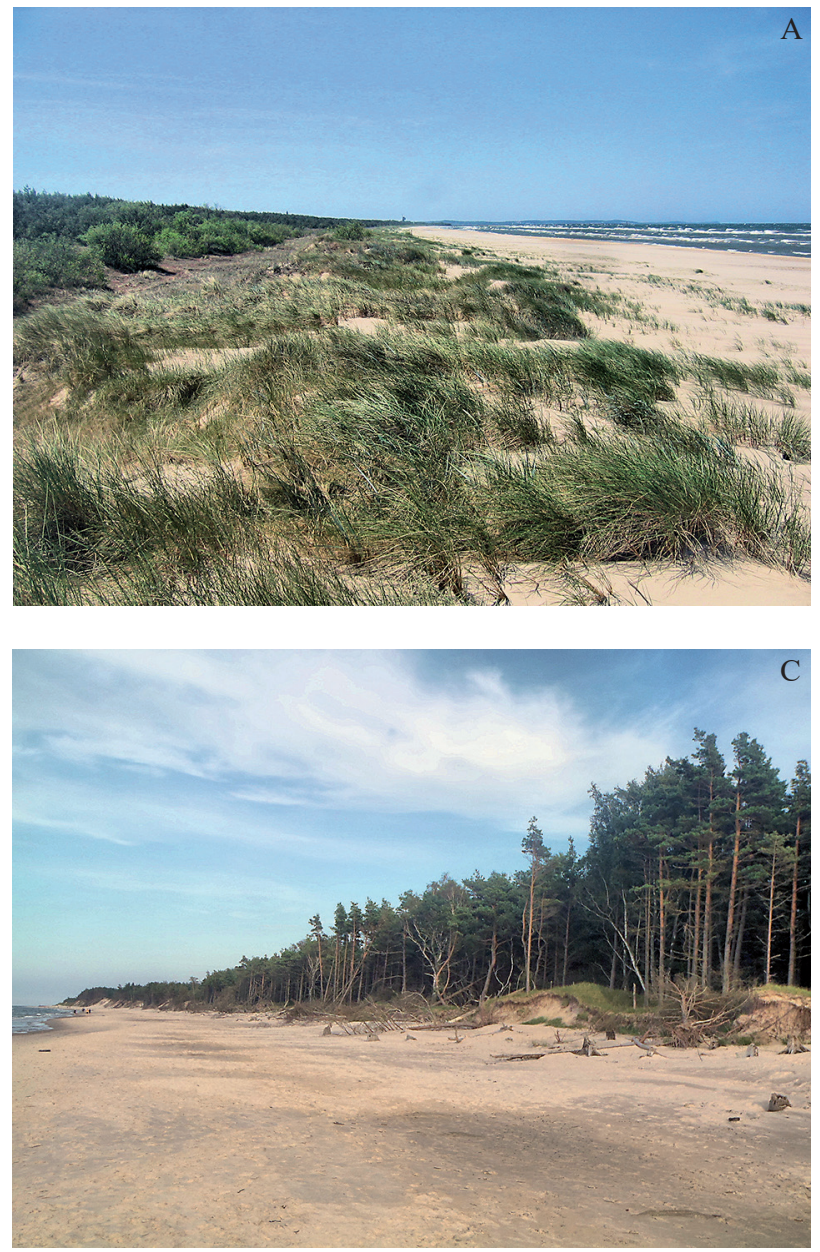

Fig. 17. Photos of different coastal dune on Polish coast

A - accumulative coast with typical foredune, Swina Gate Sandbar b - embryo dunes on the beach, Lebsko Lake Sandbar, C - low area of inland dune forms building coast, Stilo area of sandy coast, D - Undercut sides of inland dunes, Karwia Lowland Sandspit areas. In the colder seasons it is the result of strong winded bottoms of deflation forms that are reduced by about $0.35 \mathrm{~m}$. In the spring, a small accumulation occurs, with substratum growth of up to $0.15 \mathrm{~m}$.

The current relief of the Polish dune coast is very diverse (Fig. 17). The length of the naturally, accumulated coastal sections is decreasing. Human development is also covering larger sections of the coast, where mainly erosive tendencies prevail. The high diversity of coastal dune reliefs, that are repeated along the coast are the result of factor interactions, such as: the sand balance in succession, sea waves from storm surges, geological conditions and mainly the shores various exposure to impacting winds are the main forces responsible for coastal dynamics. This exposure seems to be monotonous when we look at a map of the Polish coastline. However on a closer scale there are visible undulations of the coastline in the shape of steps (like overturned stairs running from SW to NE).
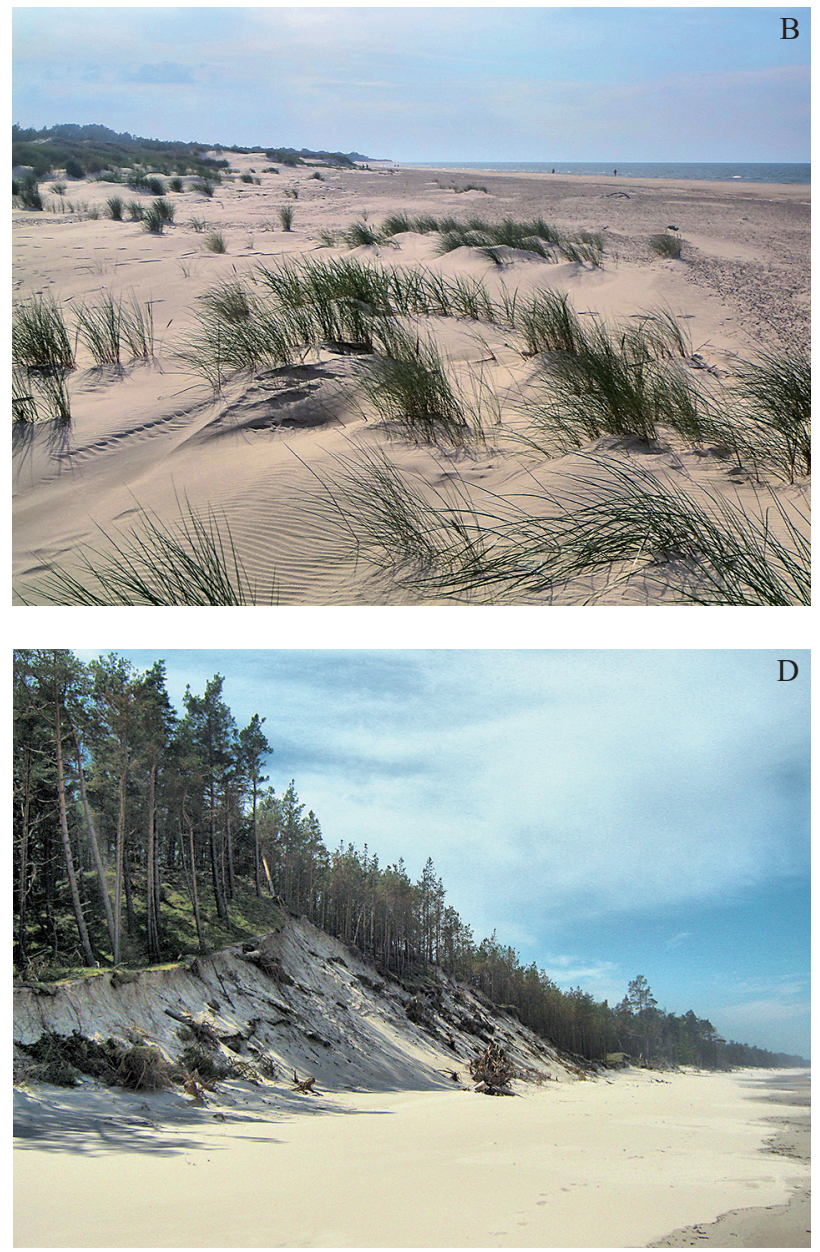

D

\section{Conclusions} the coastal zone, aeolian processes caused by wind, plants 
Certain parts of these steps that eject towards the sea are being destroyed, most frequently from the Northwest, and the concave part of these steps has a noticeable deposition of material (accumulation and foredune development). The size of these circulation cells reach 2-3 to 5 $\mathrm{km}$, and probably are related to the material balance on the shore face.

The increasing anthropopressure is deregulating this system. The processes of coastal accumulation and erosion work together and are independent of city boundaries, regions and countries. Local efforts to prevent coastal retreat, without understanding the linearity of this process cannot be successful in the long term.

The transgressive dune system along the Polish coast has been created during periods of high sediment supply from eroded coasts in rising sea level conditions. New foredunes growth is amplified by an land progradation, understood as a broadening of the beaches and shallowing of the shore face. Recently, due to the slow sea level rise, the erosion of the coast is prevailing. In these conditions dunes should retreat inland, this is natural way of dunes respond for erosion, but this is not possible in human point of view due to high coastal urbanization. The beaches are shrinking and sediment supply is decreasing. Increasingly numerous protective measures have been implemented to counteract these adverse tendencies. Longer and longer sections of the coast have been artificially supported and dunes are being reinforced with coastal protection structures. The fact is that these heavy structures strongly interfere with the natural beach processes and have limited the sand supply from erosive areas to accumulative ones. The scarcity of sand in these coastal zone is now become a bigger problem. The artificial feeding that has been used since the 90-ties on longer and longer section of the coast has become more expensive every year. Their effect is only seasonal and in the long term only changes the natural characteristics of the coast. Future scenarios of coastal dunes management and development may lead to their total artificial transformation into the typical dykes that are common in the Netherlands or may lead for preservation of natural transformation. This second scenario is more effective and valuable to local society and investors. Coastal dunes left in their natural development phases are a more efficient protection against sea level rise and flooding, where with slow coast retreat these sandy sheets can slowly retreat onto the land without totally vanishing. In this paper were presented the areas and rate of dune development under the conditions of slow sea level rise. These places with accumulative tendencies are reservoirs of sand that will be used, by coastal systems in cases of increasing erosion, for lowering negative sand balance in coastal areas. At present, the coastal accumulation that delivers material for the formation of dunes occurs on the Świna Gate Sandbar, the Łeba Lake Sandbar, on the promontory of the Hel Peninsula and at the mouths of Vistula (natural and artificial). Locally, this phenomenon can also be observed at the outlets of rivers near port-breakwaters which induce the accumulation of sedimentary material.

\section{Acknowledgment}

Since 2011, wide-ranging research on accumulative sections of the coast have been conducted as part of the project FoMoBi - Foredune Morphodynamics and Biodiversity (www.fomobi.pl), financed by the Polish National Centre for Research and Development (NCBiR).

\section{References}

Arens S.M., 1994. Aeolian processes in the Dutch foredunes. Landscape and Environmental Research Group, University of Amsterdam, Koninklijke: $150 \mathrm{pp}$.

Bagnold R.A., 1965. The physics of blown sand and desert dunes. Methuen \& Co. Ltd., London (reprint 1941): 256 pp.

Baraniecki J., Racinowski R., 1996. The application of graining parameters of the rubble from the lower part of the back-swash of the shore stream zone mto the determination of evolution tendencies of the Wolin Island coast. In: Z. Meyer (ed.), Lithodynamics of sea shore. PAS, Technical University of Szczecin, Szczecin: 27-38.

Barwis J.H., Hayes M.O., 1985. Antidunes on modern and ancient washover fans. Journal of Sedimentary Research 55(6): 907-916.

Basiński T., 1995. Dune erosion during storm surges. Journal of Coastal Research, Special Issue 22: 267-270.

Basiński T., Pruszak Z., Tarnowska M., Zeidler R., 1993. Ochrona brzegów morskich: Gdańsk. IBW PAN, Gdańsk: 320 pp.

Bauer B.O., Sherman D.J., Nordstrom K.F., Gares P.A., 1990. Aeolian transport measurements and prediction across a beach and dune at Castroville, California. In: K.F. Nordstrom, N.P. Psuty, B. Carter (eds.), Coastal dunes. Form and processes. John Wiley \& Sons Ltd., Chichester: 39-55.

Bird E.F.C., 1969. Coasts. The MIT Press, Cambridge: 242 pp.

Bird E.F.C., 1990. Foreword. In: K.F. Nordstrom, N.P. Psuty, B. Carter (eds.), Coastal dunes. Form and processes. John Wiley \& Sons, Chichester: 2-5.

Bohdziewicz L., 1963. Przegląd budowy geologicznej i typów polskich wybrzeży. Materiały do monografii polskiego brzegu morskiego. Geologia i Zagadnienia Pokrewne 5, IBW PAN, Gdańsk-Poznań: $10-41$.

Borówka M., 1979a. Przebieg procesów deflacji i akumulacji na powierzchni nadbrzeżnych wałów wydmowych. Badania Fizjograficzne nad Polską Zachodnią, XXXII, A, Geografia Fizyczna: 31-48.

Borówka M., 1979b. Rekonstrukcja rozwoju rzeźby zaplecza plaży w środkowej części mierzei Łebskiej. Badania Fizjograficzne nad Polską Zachodnią, tom XXXII, seria A, Geografia Fizyczna: 7-19,

Borówka M., Rotnicki K., 1999. Main directions of aeolian sand transport and its budget on barrier sandy beach (Łeba Barrier case study). In: R.K. Borówka, Z. Młynarczyk, A. Wojciechowski (eds.), Ewolucja geosystemów nadmorskich Południowego Bałtyku. Bogucki Wydawnictwo Naukowe, Poznań-Szczecin: 7-24.

Borówka R.K., 1980. Współczesne procesy transportu i sedymentacji piasków eolicznych oraz ich uwarunkowania i skutki na obszarze wydm nadmorskich. PTPN, Prace Komisji Geograficzno-Geologicznej XX, PWN, Warszawa-Poznań: 126 pp.

Borówka R.K., 1990. Coastal dunes in Poland. In: Th.W. Bakker, P.D. Jungerius, J.A. Klijn (eds.), Dunes of the European coasts. Catena Su pplement 18: 25-30.

Borówka R.K., 1999. Multi-year trends of change in intensity of potential aeolian transport on the West Pomeranian coast of the Balitc in the context of the morphology and present-day development of coastal dunes. In: R.K. Borówka (ed.), Late Glacial, Holocene and present-day evolution of the coastal geosystems of the Southern Baltic. Quaternary Studies in Poland, Special Issue: 67-75.

Borówka R.K., 2001. Morfologia i dynamika Wydm Łebskich. In: K. Rotnicki (eds.), Przemiany środowiska geograficznego nizin nadmorskich południowego Bałtyku w vistulianie i holocenie. Bogucki Wydawnictwo Naukowe, Poznań: 85-87.

Carter R.W.G., 1980. Human activities and geomorphic processes: the example of recreation on the Northern Ireland coast. School of biological and environmental studies, The University of Ulster, Coleraine: $7-23$. 
Carter R.W.G., 1988. Coastal environments. Academic Press, London: $617 \mathrm{pp}$.

Carter R.W.G., 1990. The geomorphology of coastal dunes in Ireland. In: Th.W. Bakker, P.D. Jungerius, J.A. Klijn (eds.), Dunes of the European coasts. Catena Supplement 18: 31-40.

Carter R.W.G., Wilson P., 1990. The geomorphological, ecological and pedological development of coastal foredunes at Magilligan Point, Northern Ireland. In: K.F. Nordstrom, N.P. Psuty, B. Carter (eds.), Coastal dunes. Form and processes. John Wiley \& Sons, Chichester: 129-157.

Cieślak A., 1995. Coastal management and protection in Poland: some legal solutions and general remarks on processes of coastal transformation. In: H.W.J. van Dijk (ed.), Management and preservation of coastal habitats. Proceedings of multidisciplinary workshop in Jastrzębia Góra, EUCC Leiden, Netherlands: 49-69.

Dubrawski R., Zawadzka-Kahlau E. (eds.), 2006. Przyszłość ochrony polskich brzegów morskich. Zakład Wydawnictw Naukowych Instytutu Morskiego w Gdańsku, Gdańsk: 302 pp.

Dziadziuszko Z., Jednorał T., 1988. Wahania poziomów morza na polskim wybrzeżu Bałtyku. Studia i Materiały Oceanologiczne 52(6), Dynamika Morza, Ossolineum: 215-238.

Fedorowicz S., Gołebiewski R., Wysiecka G., 2009. The age of the dunes of the Vistula Spit in the vivinity of Stegna. Geologija 51(3-4): 139-145.

http://dx.doi.org/10.2478/v10056-009-0015-z

Fomobi, 2013. Rozmieszczenie i morfodynamika środowiska wydm przednich i fluktuacje roślinności - bioróżnorodne siedlisko polskiego wybrzeża. Online: www.fomobi.pl - 10.06.2013.

Furmańczyk K., 1995. Coast changes of the Hel Spit over the last 40 years. In: K. Rotnicki (ed.), Polish coast: past, present, future. Journal of Coastal Research, Special Issue 22: 193-196.

Furmańczyk K.K., Dudzińska-Nowak J., Furmańczyk K.A., Paplińska-Swerpel B., Brzezowska N., 2012. Critical storm thresholds for the generation of significant dune erosion at Dziwnow Spit, Poland. Geomorphology, Special Issue 143-144: 62-68.

http://dx.doi.org/10.1016/j.geomorph.2011.09.007

Girjatowicz J.P., 2005. The Relationships Between the North Atlantic Oscillation and Southern Baltic coast ice conditions. Journal of Coastal Research 21(2): 281-291.

http://dx.doi.org/10.2112/03-0073.1

Goldsmith V., Rosen P., Gertner Y., 1990. Eolian transport measurements, winds, and comparison with theoretical transport in Israeli coastal dunes. In: K.F. Nordstrom, N.P. Psuty, B. Carter (eds.), Coastal dunes. Form and processes. John Wiley \& Sons Ltd., Chichester: 79-100.

Hartnack W., 1926. Die Küste Hinterpommerns unter besonderer Berücksichtigung der Morphologie. Jahrbuch der Pommerschen Geographischen Gesellschaft, Bd. 43/44, Greifswald: 112 pp.

Hesp P.A., 1981. The formation of shadow dunes. Journal of Sedimentary Petrology 51: 101-112.

Hesp P.A., 1984. Foredune formation of southeast Australia. In: B.G. Thom (ed.), Coastal Geomorphology in Australia. Accademic Press, Sydney: 69-97.

Hesp P.A., 1987. Morphology, dynamics and internal stratification of some established foredunes in southeast Australia. Sedimentary Geology 55: 17-41.

http://dx.doi.org/10.1016/0037-0738(88)90088-7

Hildebrandt-Radke I., 1999. Bilans transportu eolicznego na plaży Mierzei Gardnieńsko-Łebskiej. In: R.K. Borówka, Z. Młynarczyk, A. Wojciechowski (eds.), Ewolucja geosystemów nadmorskich południowego Bałtyku. Bogucki Wyd. Nauk, Poznań-Szczecin: 79-86.

Keilhack K., 1912. Die Verlandung der Swinepforte, Jahrb. der Königlische Preussischen Geology Landesanstalt 32(2): 209-244.

Kobelyanskaya J., Bobykina V.P., Piekarek-Jankowska H., 2011. Morphological and lithodynamic conditions in the marine coastal zone of the Vistula Spit (Gulf of Gdańsk, Baltic Sea). Oceanologia 53(4): 1027-1043.

http://dx.doi.org/10.5697/oc.53-4.1027

Kowalewska-Kalkowska H., Marks R., 2011. 200 years of sea level measurements at the Swinoujscie tide gauge - an unique o pportunity to study sea level variability at a regional scale. Scientific symposium
200 years of oldest continuous record of tide-gauge in Swinoujście, 18 November 2011, Świnoujście, Poland.

Łabuz T.A., 2002a. Znaczenie środowiskowe stanowisk honkenii piaskowej Honckenya peploides na wydmowym wybrzeżu Zatoki Pomorskiej. Chrońmy Przyrodę Ojczystą 58(5): 57-65.

Łabuz T.A., 2002b. Pokrycie plaż roślinnością wydmotwórczą wskaźnikiem dynamiki wybrzeża Zatoki Pomorskiej. Czasopismo Geograficzne 73(3): 245-256.

Łabuz T.A., 2003a. Współczesne przekształcenia antropogeniczne środowiska wydm nadmorskich zachodniego i środkowego wybrzeża Polski. In: J.M. Waga, K. Kocel (eds.), Człowiek w środowisku przyrodniczym - zapis działalności. PTG 3, Sosnowiec: 125-130.

Łabuz T.A., 2003b. Szata roślinna wskaźnikiem procesów eolicznych na nadmorskich wydmach mierzei jeziora Jamno. In: W. Florek (ed.), Geologia i geomorfologia pobrzeża i południowego Bałtyku, t. 5. PAP, Słupsk: 97-109,

Łabuz T.A., 2003c. Udział czynników antropogenicznych w kształtowaniu nadmorskich wydm w rejonie Mielna na mierzei jeziora Jamno. In: R.K. Borówka, A. Witkowski (eds.), Człowiek i środowisko przyrodnicze Pomorza Zachodniego. II. Środowisko abiotyczne. Wydawnictwo In Plus Oficyna, Szczecin: 66-74.

Łabuz T.A., 2003d. Initial foredune field as a factor of accumulative character of coastal dunes of the Swina Gate Barrier (West Polish coast). Oceanological and Hydrobiological Studies 32(1): 39-58.

Łabuz T.A., 2004. Coastal dune development under natural and human influence on Swina Gate Barrier (Polish coast of Pomeranian Bay). In: G. Schernewski, N. Löser (eds.), Managing the Baltic Sea. Coastline Reports 2 (2004), EUCC: 129-138.

Łabuz T.A., 2005a. Brzegi wydmowe polskiego wybrzeża Bałtyku. Czasopismo Geograficzne 76(1-2): 19-47.

Łabuz T.A., 2005b. Present-day dune environment dynamics on coast of Swina Gate Barrier (West Polish Coast). Estuarine Coastal and Shelf Science 62(3): 507-520. http://dx.doi.org/10.1016/j.ecss.2004.09.014

Łabuz T.A., 2005c. Procesy deflacji wydm nadmorskich w rejonie Kołobrzegu - studium przypadku. In: W. Florek (eds.), Geologia i geomorfologia pobrzeża i południowego Bałtyku, t. 6, PAP, Słupsk: 155-168.

Łabuz T.A., 2007a. Zapis współczesnych procesów eolicznych na Mierzei Bramy Świny w powierzchniowych poletkach badawczych. In: W. Florek (eds.), Geologia i geomorfologia pobrzeża i południowego Bałtyku, t. 7, PAP, Słupsk: 161-176.

Łabuz T.A., 2007b. Współczesne przekształcenia antropogeniczne środowiska wydm nadmorskich Mierzei Wiślanej. In: E. Smolska, P. Szwarczewski (eds.), Zapis działalności człowieka w środowisku przyrodniczym. Wydawnictwo Szkoły Wyższej Przymierza Rodzin, Warszawa: 79-88.

Łabuz T.A., 2007c. Evaluation of past and present sea holly (Eryngium maritimum) habitats on Polish coastal dunes. Acta Universitatis Latviensis, 723, Biology: 99-114.

Łabuz T.A., 2007d. Rate of the sand transportation across the beach during heavy wind action - an example from Świna Gate Sandbar. In: International Conference on Management and Restoration of Coastal Dunes. Longer abstracts version, CD, 3-5.10.2007, Santander, Spain: $1-6$.

Łabuz T.A., 2007e. Siedliska roślin psammofilnych wydm nadmorskich Mierzei Bramy Świny - ich dynamika i potrzeba ochrony. In: A. Kostrzewski, A. Andrzejewska (eds.), Zintegrowany Monitoring Środowiska Przyrodniczego. Program Zintegrowanego Monitoringu Środowiska Przyrodniczego a zadania ochrony obszarów Natura 2000. Biblioteka Monitoringu Środowiska, Warszawa: 339-354.

Łabuz T.A., 2008. Morfodynamika brzegu wydmowego w Świnoujściu. In: K. Rotnicki, J. Jasiewicz, M. Woszczyk (eds.), Holoceńskie przemiany wybrzeży i wód południowego Bałtyku - przyczyny, uwarunkowania i skutki. Wydawnictwo Tekst sp. z o.o., Poznań-Bydgoszcz: 25-34.

Łabuz T.A, 2009a. The increase of the coastal dune area of the Swina Sandbar, West Polish Coast. Zeitschrift der Deutschen Gesellschaft für Geowissenschaften 160(2): 123-135. http://dx.doi.org/10.1127/1860-1804/2009/0160-0123

Łabuz T.A., 2009b. The West Pomerania coastal dunes - alert state of their development. Zeitschrift der Deutschen Gesellschaft für Geowissenschaften 160(2): 113-122. 
http://dx.doi.org/10.1127/1860-1804/2009/0160-0113

Łabuz T.A., 2009c. Distal washover fans on Świna Gate Sandbar. Oceanological and Hydrobiological Studies 36, Suplement 1: 79-95.

Łabuz T.A., 2011. Wpływ spiętrzeń sztormowych na przebudowę profilu wybrzeża wydmowego Mierzei Bramy Świny. Czasopismo Geograficzne 82(4): 351-371.

Łabuz T.A., 2012a. Wieloletni bilans osadu wydm nadmorskich Mierzei Bramy Świny. In: M. Dłużewski, E. Rojan, I. Tsermegas (eds.), Dynamika procesów geomorfologicznych w różnych strefach morfo klimatycznych. Prace i Studia Geograficzne 49: 69-89

Łabuz T.A., 2012b. Zmienność rzeźby i położenia wydm przednich na Mierzei Wiślanej pomiędzy rokiem 2003 a 2010. In: W. Florek (ed.), Geologia i geomorfologia pobrzeża i południowego Bałtyku, t. 9, PAP, Słupsk: 111-123.

Łabuz T.A., 2012c. Zmienność morfologii brzegu wydmowego mierzei jeziora Jamno w latach 1998-2010. In: W. Florek (ed.), Geologia i geomorfologia pobrzeża i południowego Bałtyku, t. 9, PAP, Słupsk: $125-144$.

Łabuz T.A., 2012d. Potencjalny wpływ planowanych podwodnych progów wzdłużbrzegowych i ostróg na zmiany brzegu w Kołobrzegu. In: W. Florek (ed.), Geologia i geomorfologia pobrzeża i południowego Bałtyku, t. 9, PAP, Słupsk: 19-32.

Łabuz T.A., 2012e. Coastal Response to Climatic Changes: Discussion with Emphasis on Southern Baltic Sea. Landform Analysis, 21: 43-55

Łabuz T.A., Grunewald R., 2007. Studies on vegetation cover of the youngest dunes of the Świna Gate Barrier (West Polish coast). Journal of Coastal Research 23(1): 160-172. http://dx.doi.org/10.2112/03-0119.1

Łabuz T.A., Kowalewska-Kalkowska H., 2011. Coastal erosion on the Świna Gate Sandbar (southern Baltic Sea) caused by a heavy storm surge in November 2004. Climate Research, Special Issue 48: $93-$ 101 . http://dx.doi.org/10.3354/cr00927

Łabuz T.A., Olechnowicz P., 2004. Rekonstrukcja rozwoju rzeźby akumulacyjnego brzegu wydmowego na podstawie struktur sedymentacyjnych - studium przypadku z Mierzei Bramy Świny. In: M. Błaszkiewicz, P. Gierszewski (eds.), Rekonstrukcja i prognoza zmian środowiska przyrodniczego w badaniach geograficznych. Prace Geograficzne 200, IG i PZ PAN, Warszawa: 237-248,

Łabuz T.A., Osóch P., 2012. Dynamika rzeźby akumulacyjnego odcinka brzegu wydmowego w rejonie Dźwirzyna. In: W. Florek (ed.), Geologia i geomorfologia pobrzeża i południowego Bałtyku, t. 9, PAP, Słupsk: 97-109.

Łabuz T.A., Skrzypiński K., 2012. Zmienność rzeźby aktywnego odcinka ustabilizowanych wydm nadmorskich w rejonie Dźwirzyna - studium przypadku. In: W. Florek (ed.), Geologia i geomorfologia pobrzeża i południowego Bałtyku, t. 9, PAP, Słupsk: 145-158.

Marsz A., 1966. Geneza wydm łebskich w świetle współczesnych procesów brzegowych. Prace Komisji Geograficzno-Geologicznej 4(6), PTPN Poznań: 67 pp.

Mielczarski A., 1997. Ostatnie pięćset lat rozwoju Mierzei Wiślanej. W W. Florek (eds.), Geologia i geomorfologia pobrzeża i południowego Bałtyku, t. 3, PAP, Słupsk: 195-210.

Mielczarski A., Onoszko J., 1968. Poprzeczne formy akumulacji eolicznej na plażach piaszczystych oraz analiza transportu eolicznego piasków plażowych. Archiwum Hydrotechniki 15(2): 175-194.

Mierzeja Bramy Świny, 2013. Mierzeja Bramy Świny. Online: bramaswiny.szc.pl - 10.06.2013.

Miętus M., Filipiak J., Owczarek M., 2004. Klimat wybrzeża południowego Bałtyku. Stan obecny i perspektywy zmian. In: J. Cyberski (ed.), Środowisko polskiej strefy południowego Bałtyku. GTN, Gdańsk: 11-45.

Miszalski J., 1973. Współczesne procesy eoliczne na pobrzeżu słowińskim. Studium fotointerpretacyjne. Dokumentacja Geograficzna 3, IG PAN, Warszawa: $150 \mathrm{pp}$.

Mojski J.E., 1995. Geology and evolution of the Vistula Delta and Vistula Bar. In: K. Rotnicki (ed.), Polish coast: past, present, future. Journal of Coastal Research, Special Issue 22: 141-149.

Mojski J.E., 2000. The evolution of the Southern Baltic coastal zone. Oceanologia 42(3): 285-303.

Musielak S. (ed.), 1991. Photointerpretation Atlas of the shore dynamics of the western coast of Poland. Urząd Morski, Instytut Nauk o Morzu,
Okręgowe Przedsiębiorstwo Geodezyjno-Kartograficzne, Szczecin: 22 pp.

Musielak S., 1980. The present coastal processes in the Bay of Gdańsk. Research problems in the Baltic area. Peribalticum 1: 17-29.

Musielak S., 1989. Morfolitodynamika morskich plaż piaszczystych, Studia i Materiały Oceanologiczne 54, Brzeg Morski 1: 68-77.

Musielak S., 1995. Shoreline dynamics between Niechorze and Świnoujście. In: K. Rotnicki (ed.), Polish coast: past, present, future. Journal of Coastal Research, Special Issue 22: 288-291.

Musielak S., Łabuz T.A., Wochna S., 2005. Współczesne procesy brzegowe na Wybrzeżu Trzebiatowskim. In: R.K. Borówka, S. Musielak (eds.), Środowisko przyrodnicze wybrzeży Zatoki Pomorskiej i Zalewu Szczecińskiego. Wybrane aspekty. PTG, Instytut Nauk o Morzu US, Wydawnictwo Oficyna In Plus, Szczecin: 61-71.

Niespodzińska L., 1980. Eolian transport of beach material, Lubiatowo 1976. Rozprawy Hydrotechniczne 41: 213-215.

Nordstrom K.F., 2000. Beaches and dunes of developing coasts. Cambridge University: $280 \mathrm{pp}$. http://dx.doi.org/10.1017/CBO9780511549519

Nowaczyk B., 1986. Wiek wydm, ich cechy granulometryczne i strukturalne, a schemat cyrkulacji atmosferycznej w Polsce w późnym vistulianie i holocenie. Geografia 28, Wydawnictwo Naukowe UAM, Poznań: 245 pp.

Osadczuk K., 2004. Geneza i rozwój wałów piaszczystych Bramy Świny w świetle badań morfometrycznych i sedymentologicznych. Rozprawy i Studia 552, Wydawnictwo Naukowe Uniwersytetu Szczecińskiego: 212 pp.

Pawłowski S., 1922. Charakterystyka morfologiczna wybrzeża polskiego. Poznańskie Towarzystwo Naukowe, Poznań.

Pazdro Z., 1948. Półwysep Hel i jego geneza. Technika Morza i Wybrzeża 1-2: 7-13.

Piotrowska H., 1995. Forest and man on the Polish Baltic coast. In: H.W.J. van Dijk (ed.), Management and preservation of coastal habitats. Proceedings of multidisciplinary workshop in Jastrzębia Góra, EUCC Leiden, Netherlands: 121-132.

Piotrowska H., Celiński F., 1965. Zespoły psammofilne wysp Wolina i południowo-wschodniego Uznamu. Badania Fizjograficzne nad Polską Zachodnią 16: 123-170.

Piotrowska H., Doody J.P., Łabuz T.A., 2008. Polish coastal dunes. In: J.P. Doody (ed.), Sand Dune Inventory of Europe. 2nd Ed. National Coastal Consultants and EUCC - The Coastal Union, IGU Coastal Commission: 17-26.

Piotrowska H., Gos K., 1995. Coastal dune vegetation in Poland. Diversity and development. In: H.W.J. van Dijk (ed.), Management and preservation of coastal habitats. Proceedings of multidisciplinary workshop in Jastrzębia Góra, EUCC Leiden, Netherlands: 71-82.

Piotrowska H., Stasiak J., 1982. Naturalne i antropogeniczne zmiany strefowe flory naczyniowej bezleśnych wydm nadmorskich Mierzei Wiślanej. Fragmenta Floristica et Geobotanica 28(3): 372-396.

Piotrowski A., 1999. Etapy rozwoju Bramy Świny. In: R.K. Borówka, A. Piotrowski, Z. Wiśniowski (eds.), Problemy geologii, hydrogeologii i ochrony środowiska wybrzeża morskiego Zachodniego Pomorza. Przewodnik LXX Zjazdu Naukowego PTG, Szczecin: 215-241.

Polish dunes, 2013. Polish dunes. Online: polishdunes.szc. pl - 10.06.2013.

Prusinkiewicz Z., Noryśkiewicz B., 1966. Zagadnienie wieku bielic na wydmach brunatnych Mierzei Świny w świetle analizy palynologicznej i datowania radiowęglem $\mathrm{C}^{14}$. Zeszyty Naukowe Uniwersytetu Mikołaja Kopernika 14(5): 75-88.

Pruszak Z., Zawadzka E., 2005. Vulnerability of Poland's to sea-level rise. Coastal Engineering Journal 47(2-3): 131-155. http://dx.doi.org/10.1142/S0578563405001197

Pruszak Z., Zawadzka E., 2008. Potential implications of sea-level rise for Poland. Journal of Coastal Research 24(2): 410-422. http://dx.doi.org/10.2112/07A-0014.1

Psuty N.P., 1988. Sediment budget and dune/beach interaction. Journal of Coastal Research, Special Issue 3, Portland: 1-4.

Psuty N.P., 1990. Foredune mobility and stability, Fire Island, New York. In: K.F. Nordstrom, N.P. Psuty, B. Carter (eds.), Coastal dunes, forms and processes. John Wiley \& Sons Ltd., Chichester: 159-176.

Pye K., 1990. Physical and human influences on coastal dune development between the Ribble and Morsey estuaries, northwest England. 
In: K.F. Nordstrom, N.P. Psuty, B. Carter (eds.), Coastal dunes, forms and processes. John Wiley \& Sons Ltd., Chichester: 339-359.

Racinowski R., Seul C., 1996. Actual morphodynamic attributes of Szczecin shore. In: Z. Meyer (ed.), Lithodynamics of sea shore. PAS, Technical University of Szczecin, Szczecin: 107-116.

Racinowski R., 1995. Cechy litodynamiczne podbrzeża Mierzei Dziwnowskiej w świetle badań uziarnienia i składu minerałów ciężkich rumowiska. Marine Sciences 3: 7-48.

Racinowski R., Seul C., 1998. Eolic differentiation in the granulation of ruble on the marine dune shore of Dziwnów Sandbar. In: R. Gołębiewski (ed.), Periblaticum 6, PWN, Gdańsk: 65-86.

Reimann T., Tsukamoto S., Harff J., Osadczuk K., Frechen M., 2010. Reconstruction of Holocene coastal foredune progradation using luminescence dating an example from the Swina barrier (southern Baltic Sea, NW Poland). Geomorphology 132: 1-16. http://dx.doi.org/10.1016/j.geomorph.2011.04.017

Reinke J., 1911. Stüdien über die Dünen unserer Ostsesküste. II, III, Wiss. Meeresunters. Kiel, N.F. Bd. 12: 101 pp.

Rosa B., 1963. O rozwoju morfologicznym wybrzeża Polski w świetle dawnych form brzegowych. Studia Societatis Scientarum Torunensis, V: $172 \mathrm{pp}$.

Rosa B., 1984. Rozwój brzegu i jego odcinki akumulacyjne. In: B. Augustowski (ed.), Pobrzeże Pomorskie. GTN, Ossolineum, WrocławWarszawa-Gdańsk: 67-119.

Rosa B., Wpych K., 1980. O mierzejach wybrzeża południowobałtyckiego. In: B. Rosa (ed.), Peribalticum 5, GTN, Wydział Nauk o Ziemi, Gdańsk: 31-44.

Rotnicka J., 2011a. Factors controlling the development of foredunes along the Łeba Barrier on the south Baltic coast of Poland. Journal of Coastal Research SI 64: 308-313.

Rotnicka J., 2011b. Impact of beach surface type on the rate of sand transport by wind. Journal of Coastal Research SI 64: 2058-2062.

Rotnicki K., Borówka R.K., 1990. Impact of a future sea level rise in the Polish Baltic coastal zone. In: J.G. Titus (ed.), Changing Climate and the Coast. Vol. II. U.S. Environmental Protection Agency, Washington D.C.: 248-263.

Rotnicki K., Borowka R.K., 1995. Shoreline changes of the Łeba barrier in modern times. In: K. Rotnicki (ed.), Polish coast: past, present, future. Journal of Coastal Research, Special Issue 22: 271-274.

Rucińska-Zjadacz M., Rudowski S., Wróblewski R., 2009. Geneza, stan i rozwój barier piaszczystych Zatoki Puckiej. In: A. Kostrzewski, R. Paluszkiewicz (eds.), Geneza, litologia i stratygrafia utworów czwartorzędowych. T. 5, Poznań: 493-504.

Rudowski S., 1986. Środowisko sedymentacyjne rewowego wybrzeża na przykładzie południowego Bałtyku. Studia Geologica Polonica LXXXVII, IV: 76 pp.

Sydor P., Łabuz T. A., Mańkowska A., 2011. Struktury sedymentacyjne i uziarnienie osadów wydm i plaży wybrzeża Bałtyku w rejonie Pogorzelicy. Czasopismo Geograficzne 82(3): 213-233.

Sydor P., Łabuz T.A., 2012. Rozwój rzeźby plaży i wydm nadmorskich w pobliżu Pogorzelicy na podstawie badań struktur sedymentacyjnych. Przegląd Geograficzny 84(1): 123-137.
http://dx.doi.org/10.7163/PrzG.2012.1.7

Sztobryn M., Stigge H., Wielbińska D., Weidig B., Stanisławczyk I., Kańska A., Krzysztofik K., Kowalska B., Letkiewicz B., Mykita M., 2005. Storm surges in the southern Baltic (western and central parts). Report 39, Bundesamt für Seeschifffahrt und Hydrographie, Hamburg: 23 pp.

Tobolski K., 1972. Wiek i geneza wydm przy południowo-wschodnim brzegu jeziora Łebsko. Badania Fizjograficzne nad Polską Zachodnią, 25, B: $35-146$.

Tobolski K., 1980. The fossil soils of the coastal dunes on the Łeba Bar anfd their paleogeographical interpretation. Questiones Geographicae 6: 83-97.

Tomczak A., 1995a. Geological structure and Holocene evolution of the Polish coastal zone. In: K. Rotnicki (ed.), Polish coast: past, present, future. Journal of Coastal Research, Special Issue 22: 15-31.

Tomczak A., 1995b. Relief, geology and evolution of the Hel Spit. In: K. Rotnicki (ed.), Polish coast: past, present, future. Journal of Coastal Research, Special Issue 22: 181-185.

Tomczak A., 1999. Storm overflows in the western part of the Hel Peninsula on maps from the years 1694, 1818 and 1844, and Its Contemporary Relief. In: R. Gołębiewski (ed.), Peribalticum 7. GTN, Gdańsk: 89-98.

Uścinowicz S., 2003. Relative sea-level changes, glacio-isostatic rebound and shoreline displacement in the Southern Baltic. Polish Geological Institute, Special Papers 10: 79 pp.

Wróblewski A., 1975. Prawdopodobieństwo maksymalnych rocznych poziomów morza w Nowym Porcie, Kołobrzegu i Świnoujściu. Oceanology 6: 37-51.

Wróblewski A., 1998. The effect of the North Sea on oscillations of the mean monthly sea coast during the period 1900-2100. Quaternary Studies, Special Issue: 77-83.

Wróblewski R., 2001. Facje stożków przelewowych w rozwoju barier piaszczystych. In: W. Florek (ed.), Geologia i geomorfologia pobrzeża i południowego Bałtyku, t. 4, PAP, Słupsk: 183-192.

Wróblewski R., 2009. Lithodynamical facies of a sandy barrier - Hel Peninsula as an example. Oceanological and Hydrobiological Studies 38, Suplement 1: 147-161.

Zawadzka-Kahlau E., 1995. Lithodynamic processes along the Lake Jamno Spit. Geological Quarterly 39(3): 423-438.

Zawadzka-Kahlau E., 1999. Tendencje rozwojowe polskich brzegów Bałtyku Południowego. IBW PAN, Gdańsk: 147 pp,

Zawadzka-Kahlau E., 2009. Influence of sea bottom relief on coastal processes of the Southern Baltic. Geologija 51(3-4): 109-124.

Zawadzka-Kahlau E., 2012. Morfodynamika brzegów wydmowych południowego Bałtyku. Wydawnictwo Uniwersytetu Gdańskiego, Gdańsk: 353 pp.

Zeidler R.B., Wróblewski A., Miętus M., Dziadziuszko Z., Cyberski J., 1995. Wind, wave and storm surge regime at the Polish Baltic coast. In: K. Rotnicki (ed.), Polish coast: past, present, future. Journal of Coastal Research, Special Issue 22: 33-55. 